\title{
Genotype-phenotype relationships in Berardinelli-Seip congenital lipodystrophy
}

\author{
L Van Maldergem, J Magré, T E Khallouf, T Gedde-Dahl Jr, M Delépine, O Trygstad, \\ E Seemanova, T Stephenson, C S Albott, F Bonnici, V R Panz, J-L Medina, P Bogalho, \\ F Huet, S Savasta, A Verloes, J-J Robert, H Loret, M de Kerdanet, N Tubiana-Rufi, \\ A Mégarbané, J Maassen, M Polak, D Lacombe, C R Kahn, E L Silveira, F H D'Abronzo, \\ F Grigorescu, M Lathrop, J Capeau, S O'Rahilly
}

See end of article for authors' affiliations

Correspondence to: Dr L Van Maldergem Centre de Génétique Humaine, Institut de Pathologie et de Génétique, Allée des Templiers 41, B-6280

Loverval, Belgium;

vmald@skypro.be

Revised version received 10 May 2002

Accepted for publication 20 June 2002

\begin{abstract}
Generalised lipodystrophy of the Berardinelli-Seip type (BSCL) is a rare autosomal recessive human disorder with severe adverse metabolic consequences. A gene on chromosome 9 (BSCL1) has recently been identified, predominantly in African-American families. More recently, mutations in a previously undescribed gene of unknown function (BSCL2) on chromosome 11, termed seipin, have been found to be responsible for this disorder in a number of European and Middle Eastern families. We have studied the genotype/phenotype relationships in 70 affected subjects from 44 apparently unrelated pedigrees of diverse ethnic origin. In all subjects, hepatic dysfunction, hyperlipidaemia, diabetes mellitus, and hypertrophic cardiomyopathy were significant contributors to morbidity with no clear differences in their prevalence between subjects with BSCL1 or BSCL2 and those with evidence against cosegregation with either chromosome 9 or 11 (designated BSCLX). BSCL2 appears to be a more severe disorder than BSCL1 with a higher incidence of premature death and a lower prevalence of partial and/or delayed onset of lipodystrophy. Notably, subjects with BSCL2 had a significantly higher prevalence of intellectual impairment than those with BSCL1 or BSCLX ( $p<0.0001$, OR 17.0, Cl 3.6 to 79.0). The higher prevalence of intellectual impairment and the increased risk of premature death in BSCL2 compared to BSCL1 emphasise the importance of molecular diagnosis of this syndrome and have clear implications for genetic counselling.
\end{abstract}

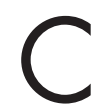
ongenital lipodystrophy of the Berardinelli-Seip type (BSCL, OMIM 269700) is a rare condition characterised by a near total absence of adipose tissue..$^{1-3}$ Because of the absence of functional adipocytes, dietary and endogenously synthesised lipid is stored aberrantly in metabolically important tissues such as muscle and liver. This leads to severe insulin resistance and, ultimately, diabetes mellitus, which is often difficult to control. Other metabolic consequences include hypertriglyceridaemia, which can be severe, and hepatic steatosis, which can progress to cirrhosis and death from hepatic failure. For reasons as yet unexplained, affected subjects also frequently develop a hypertrophic cardiomyopathy that can lead to death from cardiac failure. Acanthosis nigricans, acromegaloid features, and muscle hypertrophy are also found. ${ }^{4-7}$

The high incidence of parental consanguinity and high recurrence rate among sibs has long suggested that BSCL is usually an autosomal recessive condition. Studies in Norwegian patients suggested a founder effect traced back to the fourteenth century. ${ }^{8}$ An initial genome wide scan performed in a multi-ethnic set of consanguineous families failed to identify a locus displaying significant homozygosity by descent.' Subsequently, Garg et al ${ }^{10}$ identified a gene on chromosome 9q34 (BSCL1) that was linked to the disease in 17 of 19 families, mostly of African-American origin. Magré et $a l^{11}$ reported that this locus was unlikely to be responsible for the majority of affected families in other ethnic groups and, using extensive family material from Norway and the Lebanon, identified a second locus on 11q13 (BSCL2). ${ }^{11}$ In the 1lq13 linked families, multiple different homozygous and compound heterozygous mutations were found in a previously undescribed gene, termed seipin.

The seipin gene encodes a protein of unknown function with little homology to known proteins. Surprisingly, this gene is widely expressed, with particularly high expression levels in the brain. Intellectual impairment has frequently been mentioned in more than 100 published clinical (case) reports of BSCL, but has often been attributed to factors such as the non-specific effects of chronic illness in childhood and/or the adverse social consequences of the very abnormal appearance of these children. The large number of affected subjects in the international consortium, which collaborated to identify the BSCL2 gene, provided us with an opportunity to examine the genotype/phenotype relationship in this disease.

\section{MATERIALS AND METHODS}

\section{Description of cohort}

All studies were performed with the informed consent of the subjects and/or their recognised guardians and with the formal approval of local institutional ethics committees. Patients included in the cohort presented with lipoatrophy, hyperlipidaemia (in the vast majority of cases, hypertriglyceridaemia), hepatomegaly, acromegaloid features, and insulin resistance. Seventy affected subjects from 44 independent pedigrees were studied. The families originated from a wide range of ethnicities and geographical locations (Appendix 2).

\section{Genotyping}

BSCL families were classified as BSCL1, BSCL2, or BSCLX on the basis of mutational analysis and haplotype analysis. All subjects classified as BSCL2 had homozygous or compound heterozygous mutations in the seipin gene. Subjects were classified as BSCLl if there was evidence for cosegregation with chromosome 9q, but not with llq. Two families showed evidence against cosegregation with either $9 \mathrm{q}$ or $1 \mathrm{lq}$ and were termed BSCLX. One family was unclassifiable as no seipin 
Table 1 Clinical features of patients with lipodystrophy. Group 1 (BSCL2) was defined by the presence of mutations in the seipin gene, while group 2 contains all other types of BSCL. Putative linkage on chromosome 9 defined group 3 (BSCL1). Nominal variables are expressed as prevalence rate (\%) and were analysed by chi-square test. Numerical variables are expressed as mean (SEM) and significance was calculated by Mann-Whitney test. Statistical significance was considered at $\mathrm{p}<0.05$ comparing group 1 with groups 2 or 3 .

\begin{tabular}{|c|c|c|c|c|c|c|c|}
\hline & \multicolumn{2}{|l|}{$\begin{array}{l}\text { Group } 1 \\
\text { BSCL2 }\end{array}$} & \multicolumn{2}{|c|}{$\begin{array}{l}\text { Group } 2 \\
\text { BSCL1/X/non-informative }\end{array}$} & \multirow{2}{*}{$\begin{array}{l}\text { Group } 3 \\
\text { BSCL1 } \\
\begin{array}{l}\text { (Index) } \\
(n=17)\end{array}\end{array}$} & \multirow[b]{2}{*}{ p $1 / 2$} & \multirow[b]{2}{*}{ P $1 / 2$} \\
\hline & $\begin{array}{l}\text { (Index) } \\
(n=24)\end{array}$ & $\begin{array}{l}\text { Relatives } G 1 \\
(n=21)\end{array}$ & $\begin{array}{l}(\text { Index }) \\
(n=20)\end{array}$ & $\begin{array}{l}\text { Relatives } G 2 \\
(n=5)\end{array}$ & & & \\
\hline Gender (F/M) & $10 / 14$ & $8 / 13$ & $15 / 5$ & $3 / 2$ & $13 / 4$ & 0.02 & 0.02 \\
\hline Mean age $(y)$ & $20.8(2.6)$ & $18.5(3.3)$ & $20.3(2.8)$ & $24.0(4.6)$ & $21.6(2.8)$ & NS & NS \\
\hline Death $(\%)$ & 16.7 & 14.3 & 10.0 & 0.0 & ONQS & NS & \\
\hline Age at death (y) & $26.2(4.7)$ & $20.7(10.2)$ & 4.5 & - & - & NS & NS \\
\hline Congenital lipoatrophy (\%) & 75.0 & 85.0 & 52.6 & 100.0 & 56.2 & NS & NS \\
\hline Age of delayed lipoatrophy (mth) & $3.0(1.6)$ & $1.9(1.8)$ & $29.5(17.5)$ & - & $34.3(20.6)$ & NS & NS \\
\hline Average birth weight $(\mathrm{g})$ & $3022(150)$ & $3076(120)$ & $2845(130)$ & $2910(340)$ & 3007 (115) & NS & NS \\
\hline Defect in birth weight (10th) & 23.8 & 33.3 & 27.7 & 50.0 & 12.5 & NS & NS \\
\hline Diabetes mellitus (\%) & 45.8 & 23.8 & 35.0 & 0.0 & 35.3 & NS & NS \\
\hline Age of onset of diabetes $(y)$ & $14.7 \pm 1.9$ & $24.8 \pm 2.7$ & $14.3 \pm 3.5$ & - & $16.3 \pm 3.4$ & NS & NS \\
\hline Hypertrophic cardiomyopathy (\%) & 33.3 & 14.2 & 25.0 & 0.0 & 23.5 & NS & NS \\
\hline Bone cysts (\%) & 8.3 & 4.8 & 25.0 & 40.0 & 23.5 & NS & NS \\
\hline Intellectual impairment (\%) & 75.0 & 85.0 & 15.0 & 0.0 & 11.8 & 0.0001 & 0.0001 \\
\hline Parental consanguinity (\%) & 70.8 & ND & 45.0 & ND & 52.9 & NS & NS \\
\hline African ancestry $(\%)$ & 0.0 & ND & 35.0 & ND & 58.2 & 0.005 & 0.002 \\
\hline
\end{tabular}

mutation was found and haplotype analysis at chromosome 9 was uninformative.

\section{Phenotypic evaluation}

Each participant was evaluated by history, physical examination, and review of medical records. Participating investigators completed a standardised 98 item questionnaire. A formal assessment of intelligence quotient (IQ) was available only for a minority. Therefore, a simplified scale, based largely on educational performance, was used to assess whether there was mild, moderate, or severe intellectual impairment (Appendix 1).

\section{Statistical analysis}

From all 70 affected subjects, we considered only index cases $(\mathrm{n}=44)$ for statistical analysis while the remaining patients $(n=26)$ were included in a group of relatives. Patients genotyped as BSCL2 $(n=24)$ displayed evidence for mutations in the seipin gene on chromosome 11q. All other index cases with lipodystrophy $(n=20)$ were considered as a unique group (BSCLs). Evidence provided for cosegregation with chromosome 9q allowed further classification as BSCL1 $(n=17)$. Index patients lacking evidence for cosegregation with chromosomes $11 \mathrm{q}$ or $9 \mathrm{q}$ were classified as $\operatorname{BSCLX}(\mathrm{n}=3)$. One patient was unclassifiable and, as such, uninformative. Congenital lipoatrophy (presence of lipoatrophy at birth) was introduced as a nominal (bimodal) variable whereas delayed lipoatrophy was introduced as a numerical variable as a function of age (month). Similarly, diabetes mellitus was introduced as a nominal variable and age of onset, when specified, was considered as a numerical variable (years). Birth weight was considered as a numerical variable $(\mathrm{g})$. However, hypotheses were tested for the presence of defect in birth weight and, in this case, nominal variables were considered as defects defined under the 25 th or 10th centile. Mental impairment was introduced either as a bimodal nominal variable or as a scoring index with four levels (no defect, mild, moderate, and severe). Ethnic origin (African/ white) and consanguinity were introduced as bimodal nominal variables. Nominal and numerical variables were analysed with chi-square and non-parametric Mann-Whitney tests, respectively. Statistically significant values were considered at $\mathrm{p}<0.05$. For the multivariate analysis, logistic regression was performed with a plurimodal equation as provided by StatView 5.0 software (Abacus Concepts, Berkeley, CA). Significant values $(p<0.1)$ were introduced into the model equation, except data for genotyping (used for classification of groups). In the first step we compared the BSCL2 group against all other lipodystrophies but distinct groups of BSCLl and BSCLX were also tested. Data in tables are expressed as prevalence rates (\%) or as mean (SEM) in different groups of index cases and relatives.

\section{RESULTS}

\section{Genotype}

The molecular genetic analyses established that, of the total 44 families, the majority (24 families) represented BSCL2 (45 affected subjects). BSCLl was the next largest subgroup with 17 families (21 affected subjects). One family was classified as BSCLX (one affected subject) and two families (three subjects) were unclassifiable. Appendix 2 shows the ethnic origin (country) of families within the three subtypes. Consistent with the previous findings of Garg et al, ${ }^{10}$ all families of African ancestry were in the BSCLl group. Seipin mutations (BSCL2) were found in predominantly white subjects from Lebanon, Portugal, and Norway. The two BSCLX families as well as the non-informative family were of white European extraction. The prevalence of parental consanguinity was greater, but not significantly so, in BSCL2 than in BSCL1 or other types of lipodystrophy (table 1).

Statistically significant differences were found when the BSCL2 group was compared to the putative BSCL1 genotype. The clinical profile of relatives of the two major BSCL types was very similar to the index cases. Ethnic differences were evident since $100 \%$ of BSCL2 cases were white, compared to only $65 \%$ in other lipodystrophies $(\mathrm{p}<0.0016)$. Interestingly, all (35\%) subjects of African ancestry were genotyped as putative BSCLl. Further detailed study of ethnic origin indicated that, among BSCL2 subjects, $24 \%$ were from Lebanon and $56 \%$ were of Portuguese origin $(\mathrm{p}<0.005)$.

\section{Phenotype}

Major phenotypic features of all three subgroups taking into account index cases (used for statistical analysis) and relatives are summarised in table 1. Several major features appeared to characterise the BSCL2 group either compared to all cases of lipodystrophy or particularly to BSCLl index cases. Thus, BSCL2 was characterised by a greater number of affected males than females, white ancestry, and highly significantly 
Table 2 Seipin mutations in mentally retarded subjects and non-mentally retarded subjects

\begin{tabular}{|c|c|c|c|c|}
\hline Mutation & & $\begin{array}{l}\text { No of patients } \\
n=45\end{array}$ & Ethnic background & MR \\
\hline \multirow[t]{7}{*}{ Nonsense 32/45 (71\%) } & F63fsX75 & 2 & $\begin{array}{l}\text { Norwegian } \\
\text { Italian (Sicily) }\end{array}$ & $\begin{array}{l}\text { Yes } \\
\text { Yes }\end{array}$ \\
\hline & F101fsX111 & 1 & Portuguese-Amazonian & No \\
\hline & $\mathrm{F} 105 \mathrm{fs} \times 111$ & 21 & Lebanese & Yes \\
\hline & $\mathrm{F} 108 \mathrm{fs} \times 113$ & 2 & Portuguese (SA) & Yes \\
\hline & & & Portuguese (SA) & No \\
\hline & $\mathrm{R} 138 \mathrm{X}$ & 5 & Portuguese & Yes \\
\hline & $\mathrm{F} 213 \mathrm{fs} \times 231$ & 1 & Indian & No \\
\hline Deletion 2/45 (4.5\%) & del E4-E6 & 2 & Portuguese & Yes \\
\hline \multirow[t]{2}{*}{ Splice site 2/45 (4.5\%) } & $\begin{array}{l}\text { 639/+1G-A } \\
\text { deltaV99-S146 }\end{array}$ & 1 & Turkish & Yes \\
\hline & $\begin{array}{l}1016 /-3 C->G \\
\text { F224deltaY225-Q271 fs X288 }\end{array}$ & 1 & Turkish & $\begin{array}{l}\text { Yes. } \\
\text { Severe developmental delay }\end{array}$ \\
\hline Missense 5/45 (1 1\%) & Ala1 12 Pro & 5 & Norwegian & Yes \\
\hline \multirow[t]{3}{*}{ Compound heterozygosity $4 / 45(8.8 \%)$} & Ala 212 Pro/F 63 fsX 75 & 1 & Norwegian & Yes \\
\hline & F105fsX112/deletion E4-E6 & 1 & Portuguese (France) & Yes \\
\hline & $\begin{array}{l}\text { F63 fsX75/1015/ }+5 G \rightarrow A \text { or splice } \\
(F 224 f \mathrm{f} X 225)\end{array}$ & 2 & British & No \\
\hline
\end{tabular}

more frequent intellectual impairment. These features were also found when one considered all studied cases (index and relatives) of BSCL2 $(n=45)$ compared to other lipodystrophies $(n=25)$. Thus, $60 \%$ of BSCL2 patients were males compared to only $28 \%$ of other lipodystrophy cases.

\section{Lipodystrophy and metabolic dysregulation}

The majority of subjects were noted to have complete lipodystrophy either at or close to the time of birth. The prevalence of congenital onset of lipoatrophy was $79.5 \%$ in BSCL2 compared to $61 \%$ in other cases. Four subjects had a reliable history of a delayed onset of lipodystrophy and all of these were in the BSCLl group. Although the congenital lipoatrophy was not significantly different among groups, it should be noted that the occurrence of lipoatrophy within the first year of life was $91 \%$ in BSCL2 patients compared to only $83 \%$ in other types of BSCL. There was a history of relative sparing of the face from the lipodystrophy in BSCLl subjects of African origin, at least during the first decade of life. Hypertriglyceridaemia was reported in all subjects with marked variation in severity, even within individual families (for example, between 3 and $90 \mathrm{~g} / \mathrm{dl}$ ). The prevalence of diabetes mellitus was similar between BSCL2 (35.5\%), BSCLl $(28.6 \%)$, and BSCLX $(25 \%)$. The mean age at onset of clinical diabetes was also similar in BSCL2 and BSCL1 (17.9 (SD 1.9) and 16.3 (SD 3.4) years, respectively), whereas the age of onset for the single BSCLX patient with diabetes was 2 years. Hepatomegaly was noted in all subjects in this study.

\section{Premature mortality}

Seven of the 45 (15.5\%) subjects in the BSCL2 group died prematurely between 14 and 35 years. Three of these deaths were the result of cardiac failure, two of renal failure, one of hepatic failure, and one of unknown cause. The non-informative subject died at the age of 19 months of cardiac failure. In contrast, all affected subjects in the BSCLl pedigrees are still alive. Although this provides some evidence for a possible locus specific effect on premature mortality, the difference between BSCL2 and BSCL1/ $\mathrm{X} /$ non-informative subgroups was not statistically significant.

\section{Other clinical features}

Skeletal muscular hypertrophy was reported in all affected subjects. The reported prevalence of hypertrophic cardiomyopathy was similar in BSCLl (19\%), BSCL2 (22\%), and BSCLX (25\%, including the non-informative patient), although the ability to make this diagnosis is highly dependent on access to echocardiography. While the documentation of bone cysts is dependent on patients having undergone appropriate radiological examination, it is worth noting that the frequency of bone cysts was increased in BSCLl index patients $(23.5 \%)$ compared to BSCL2 (8.3\%).

\section{Intellectual impairment}

Questionnaire based information regarding intellectual performance was available for BSCL1, BSCL2, and BSCLX subjects. The reported prevalence of mild or moderate intellectual impairment was remarkably high in the BSCL2 group with 78\% of subjects being affected (table 2). In contrast, only $10 \%$ of the BSCLl subgroup and the non-informative subject were reported to show evidence of intellectual impairment. The intellectual impairment found in BSCL2 was mild in 23 subjects, moderate in 11 , and severe in one subject. Of the two affected BSCLl subjects, one was mildly and the other moderately intellectually impaired. Table 2 indicates the spectrum of mutations in BSCL2 patients grouped according to the presence or absence of intellectual impairment. There was no obvious genotype-phenotype relationship. Missense, nonsense, and frameshift mutations were equally distributed between the intellectually impaired and the normal intelligence groups. Moreover, the same nonsense mutation (F108fsX113) was observed in two unrelated subjects, of whom one was mentally retarded and the other of normal intelligence.

When multivariate analysis was performed by logistic regression none of the aforementioned clinical features appeared significant, except intellectual impairment. Thus, intellectual impairment as a bimodal variable was associated with BSCL2 with $\mathrm{p}<0.0001$, OR 17.0, CI 3.6 to 79.0 with respect to all other types of lipodystrophies. If one compares the BSCL2 group with the BSCL1 group, again intellectual impairment appeared strongly associated with the BSCL2 genotype ( $\mathrm{p}<0.0001$, OR 23.5, CI 3.9 to 128.3).

\section{DISCUSSION}

We have undertaken the most comprehensive study reported to date of genotype/phenotype relationships in inherited human syndromes of congenital generalised lipodystrophy (CGL) involving 70 affected subjects from 44 independent pedigrees (fig 1). Clinically relevant findings resulting from these studies include (1) the confirmation of the existence of at least one additional CGL locus other than those on chromosomes 9 and 11, (2) the confirmation of ethnic differences in 

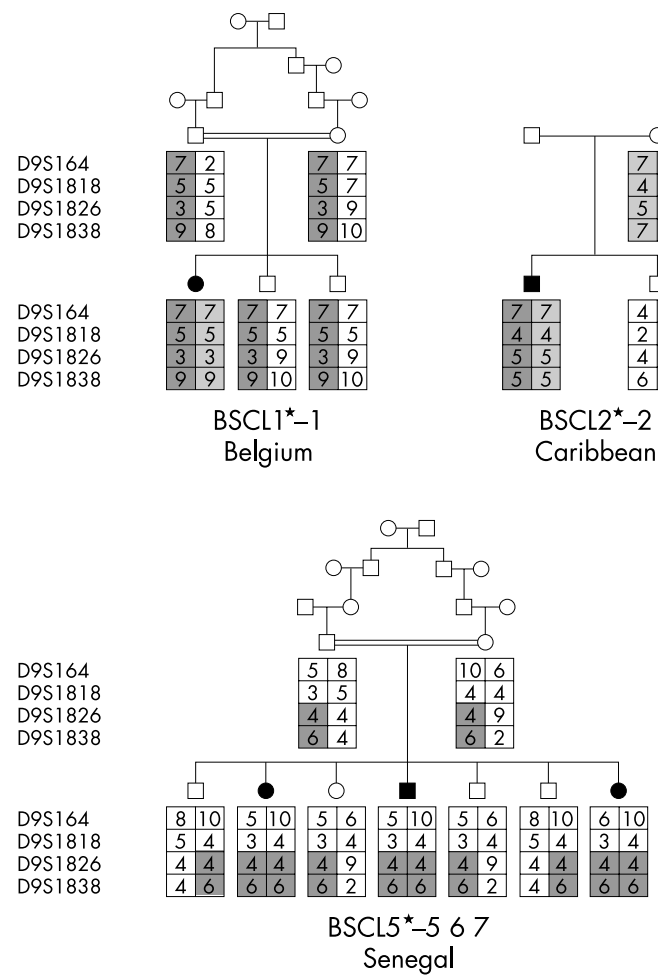

BSCL1

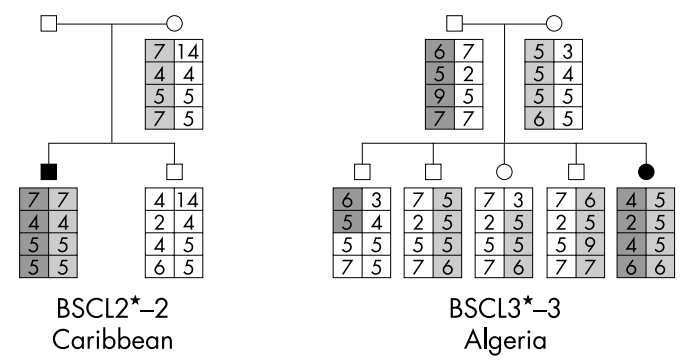

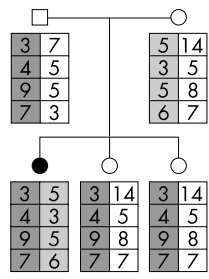

$\mathrm{BSCl}^{\star}{ }^{\star}-8$ African-Ghana

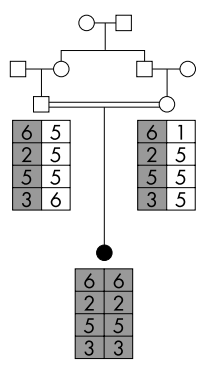

$\mathrm{BSCL}^{\star}-9$

Morocco

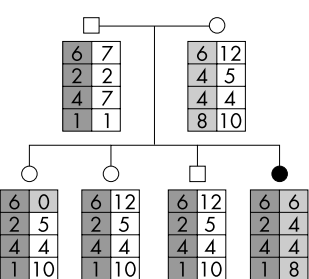

$\mathrm{BSCL} 4^{\star}-4$

South Africa

(African-mixed)
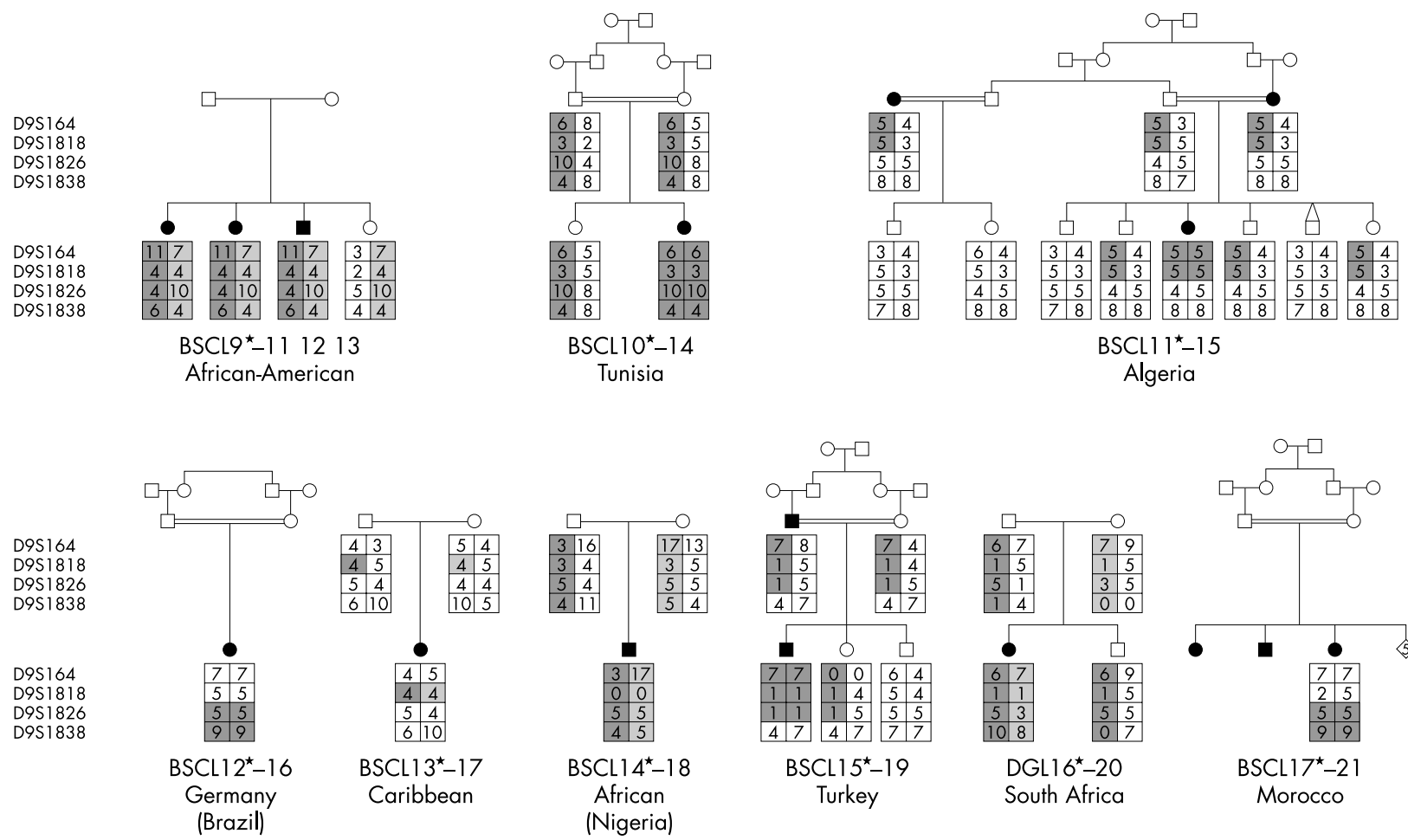

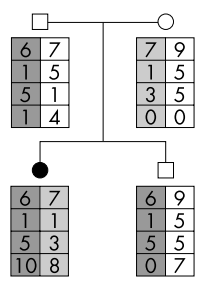

DGL $16^{\star}-20$

South Africa

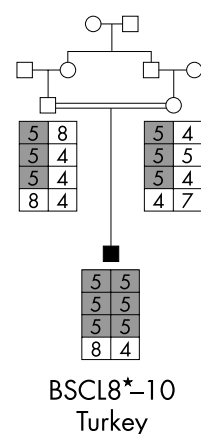

Figure 1 Family pedigrees of all participating families grouped by aetiology. For BSCL1 families, evidence for cosegregation with $9 \mathrm{q} 34$ is provided. For BSCL2, the nature of the mutation identified is indicated under the pedigree. For BSCLX, evidence against cosegregation with the 9 q34 locus is also provided.

the relative frequency of BSCL1 and BSCL2 gene defects, and (3) the establishment of certain key phenotypic differences, in particular concerning intellectual impairment, between the three subtypes of CGL.

Two Europid families in our cohort had no detectable seipin mutations and also showed evidence against the involvement of a locus at 9q34. Taken together with the data of Heathcote et $a l^{12}$ in Omani pedigrees, this strongly suggests that there must be at least one additional locus that causes BSCL. For the moment, we suggest that this be referred to as BSCLX.

Among the 44 families studied, BSCLl patients originated primarily from sub-Saharan Africa and Maghreb countries (Morocco, Algeria, Tunisia) with only a minority coming from Middle Eastern countries (for example, Turkey) and northern 
$\mathrm{BSCL} 2$
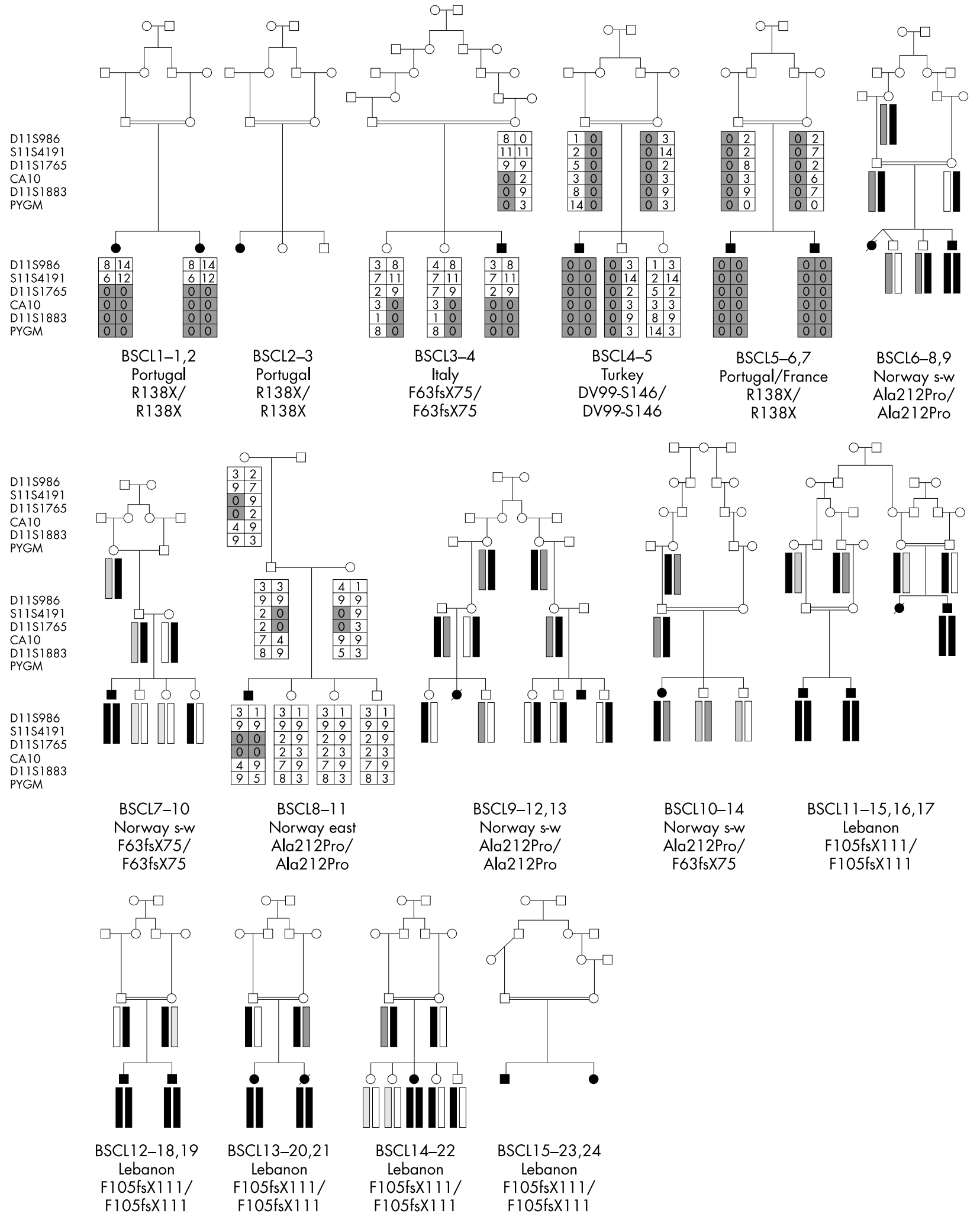

Figure 1 continued

Europe. This is consistent with the results of Garg et al, ${ }^{10}$ who found cosegregation of the disease with chromosome $9 q 34$ markers in the great majority of their families of AfricanAmerican origin. In contrast, a large number of different seipin (BSCL2) mutations were found in subjects of varying white ethnicities including Norway, United Kingdom, and Mediterranean countries, as well as Middle Eastern Arabs. Interestingly, patients from Portugal and its ancient colonies accounted for a significant proportion of subjects, suggesting a spread from the 15th century onwards. ${ }^{13}$ Notably, no 
BSCL2 (cont.)

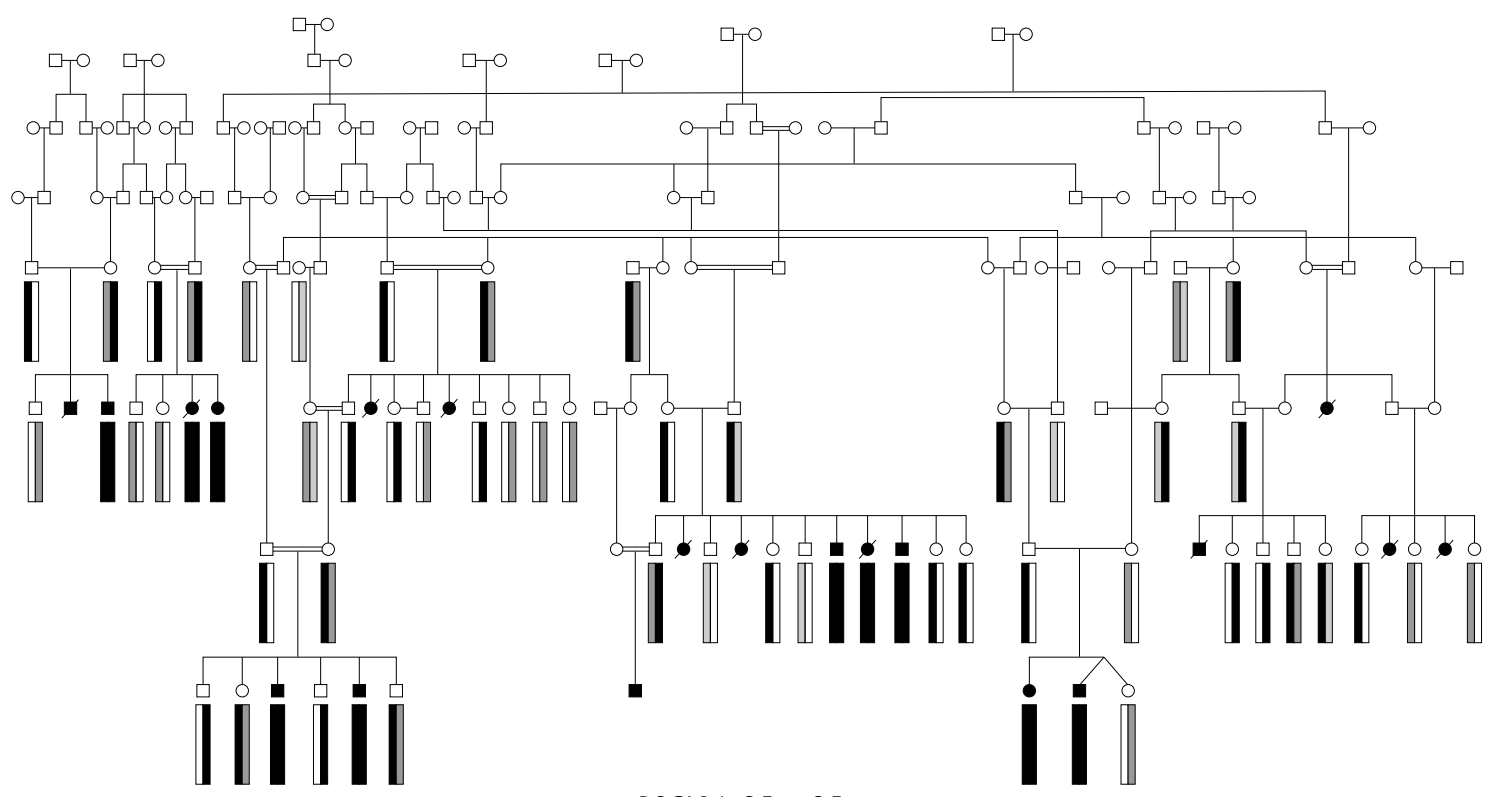

BSCL16-25 to 35

Lebanon

F105fs $\times 111 /$

F105fsX111

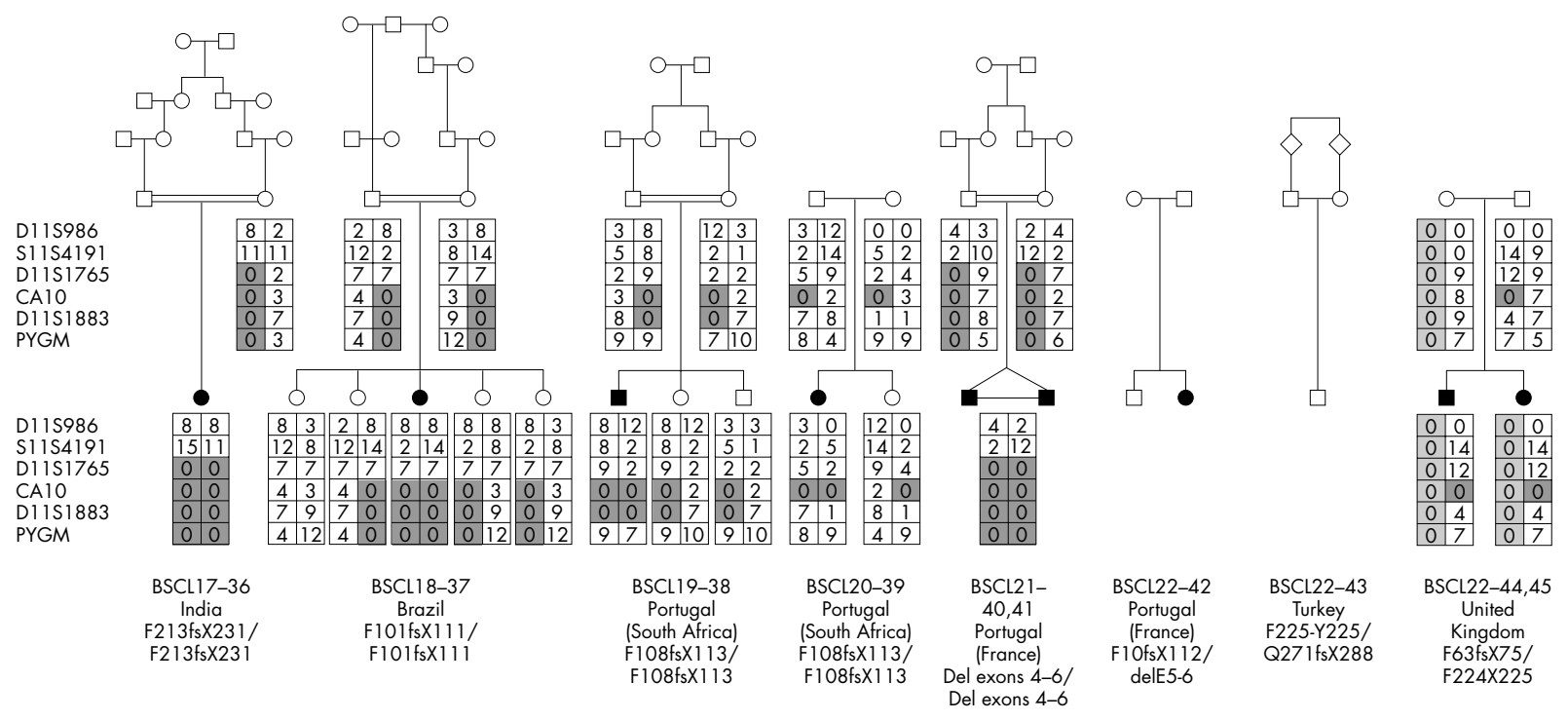

Figure 1 continued

subjects of African ancestry had seipin mutations. The two BSCLX families as well as the non-informative patient were of Europid origin.

The higher prevalence of recorded inbreeding in BSCL2 families than in BSCLl families cannot easily be evaluated as long as the various local inbreeding patterns are not known. For example, chance inbreeding has been verified in one Norwegian BSCL2 genetic compound family. Taking into account also the different ethnic origins, the simplest explanation is that the high African origin of BSCLl is the result of a single, very ancient mutation having reached an appreciable spread and allele frequency.

Phenotypic evaluation was undertaken by multiple independent physicians in several countries and patients were not examined by a single observer. Since a standardised formal assessment of intellectual capabilities was difficult to establish because of highly variable attendance at school and the wide range of ethnic and racial background, it was decided to evaluate the degree of mental impairment using a grow scale measuring social adaptation and school performance. This classification allows some overlap between severe and moderate mental retardation.

Notwithstanding these caveats, the application of standardised questionnaires across these multiple centres has allowed us to attempt to establish, with reasonable confidence, whether there are any major and consistent phenotypic differences between the genetic subtypes of this disease. Lipoatrophy was present at birth and complete in all BSCL2 and BSCLX subjects. In contrast, a subset of BSCLl subjects had evidence for lipoatrophy that was either delayed, incomplete, or both. For those subjects in whom the lipoatrophy was incomplete, the face tended to be spared. Thus, BSCLl 


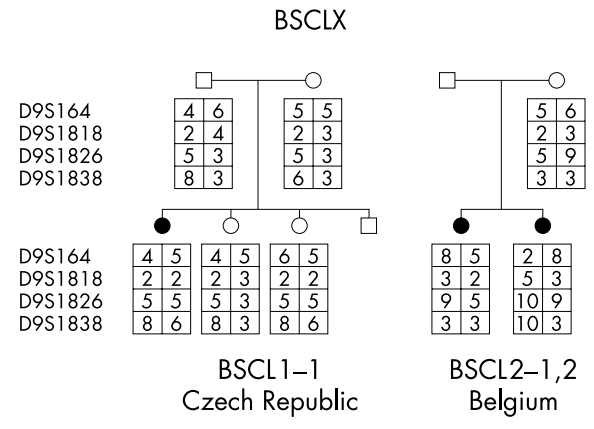

Non-informative

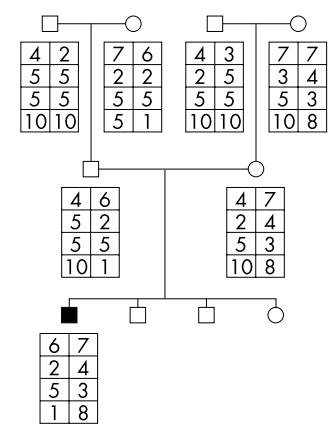

BSCL $1-1$

Czech Republic

Figure 1 continued

may show phenotypic overlap with at least two other forms of lipodystrophy that have previously been considered distinct. Acquired total lipodystrophy (Lawrence syndrome) is generally considered to be a sporadic, non-inherited condition in which total lipodystrophy, of presumed autoimmune origin, occurs often after an infectious illness. ${ }^{14}$ Our findings suggest that some cases of BSCLl in which the onset of the lipodystrophy is delayed and are of sporadic occurrence may be labelled incorrectly as having Lawrence syndrome. The distinction is made more complex by the fact that there are no diagnostic tests for Lawrence syndrome, although the lipoatrophy of this syndrome does tend to appear more suddenly than in the BSCLl cases. Familial partial lipodystrophy of the Dunnigan-Köberling type (FPLD, OMIM 151660) is an autosomal dominant, face sparing lipodystrophy caused by a particular cluster of mutations in the nuclear envelope proteins lamins $\mathrm{A} / \mathrm{C} \cdot{ }^{15-19}$ However, these patients have a distinctive cushingoid appearance of the face that makes differential diagnosis easy.

The relative effects of the BSCL subtypes on premature mortality are difficult to quantify given factors such as incomplete ascertainment in families and possible referral bias. However, it is notable that while none of the BSCLl patients included in our study died before the age of 40 (but family history death of affected subjects in early adulthood was positive in some cases), premature death was observed in seven patients from the BSCL2 subgroup. The reasons for this difference are not obvious as the prevalence of major metabolic derangements (for example, diabetes, hyperlipidaemia, and hepatic dysfunction) were similar between the groups. However, it is notable that three of the seven premature deaths in the BSCL2 group were attributed to cardiac failure, including one during pregnancy.

As these diseases are clearly autosomal recessive it was surprising that we found an excess of females in the BSCLl group and an excess of males in the BSCL2 group. In the case of BSCLl, this is most likely to represent ascertainment bias, as the appearance of lipodystrophy is often more striking in females leading to earlier referral and diagnosis. However, this would not explain the opposite sex ratio found in the BSCL2 group. Within that group, affected female subjects tended to have a more severe phenotype than males (personal observations) and this subtype is generally more lethal than BSCL1. It is possible, therefore, that earlier mortality in affected females has resulted in a systematic bias towards the referral of surviving males to the consortium.

Interestingly, radiological evidence of bone cysts was observed in 10 patients (five with BSCL1, three with BSCL2, and two with BSCLX). A syndrome of cystic angiomatosis of bones and congenital lipodystrophy (OMIM 272500) has been reported by Brunzell et al ${ }^{20}$ in 1968 and considered to be an entity separate from BSCL. Our findings suggest that this may not be a discrete entity.

The most remarkable difference between the groups was the prevalence of intellectual impairment. While it was not possible to undertake thorough and systematic quantitative assessment of IQ, it is notable that while $78 \%$ of BSCL2

\begin{tabular}{|c|c|c|c|}
\hline $\begin{array}{l}\text { Degree of } \\
\text { mental } \\
\text { retardation }\end{array}$ & Preschool years $(0-5 y)$ & School years (6-21 y) & Adulthood \\
\hline \multicolumn{4}{|l|}{ Simplified scale } \\
\hline $\begin{array}{l}\text { Mild } \\
\text { (IQ 50-70) }\end{array}$ & $\begin{array}{l}\text { Is rarely distinguishable from a normal child } \\
\text { Mildly delayed development in the } \\
\text { sensorimotor field } \\
\text { Mild language delay } \\
\text { Good social skills }\end{array}$ & $\begin{array}{l}\text { Able to acquire a basic level of education, } \\
\text { but doesn't reach the competence level of } \\
\text { the last year of primary school }\end{array}$ & $\begin{array}{l}\text { Able, with special education and special } \\
\text { training to reach a satisfactory professional } \\
\text { and social functioning } \\
\text { Often needs guidance and supervision in } \\
\text { stressful circumstances }\end{array}$ \\
\hline $\begin{array}{l}\text { Moderate } \\
(35<1 Q<50)\end{array}$ & $\begin{array}{l}\text { Learns language and communication } \\
\text { Motor development reaches a satisfactory } \\
\text { level } \\
\text { Able to acquire satisfactory autonomy } \\
\text { Able to be self-sufficient with moderate } \\
\text { controls }\end{array}$ & $\begin{array}{l}\text { Is only able to learn very few pedagogic } \\
\text { milestones } \\
\text { (Some reading, some writing and } \\
\text { calculation, usually during adolescence) }\end{array}$ & $\begin{array}{l}\text { Able to do non-qualified work, usually in a } \\
\text { protected environment } \\
\text { Needs supervision and guidance } \\
\text { Is unable to work autonomously }\end{array}$ \\
\hline $\begin{array}{l}\text { Severe } \\
(20<1 Q<35)\end{array}$ & $\begin{array}{l}\text { Poor motor development } \\
\text { Little or no language } \\
\text { Low communication skills }\end{array}$ & $\begin{array}{l}\text { Able to learn a few words } \\
\text { Able to communicate } \\
\text { Hygiene rules and minimal behavioural } \\
\text { habits are acquired } \\
\text { Unable to acquire school education }\end{array}$ & $\begin{array}{l}\text { Is able partially to earn his or her income } \\
\text { when working in a protected environment } \\
\text { and under full supervision }\end{array}$ \\
\hline $\begin{array}{l}\text { Profound } \\
(I Q<20)\end{array}$ & $\begin{array}{l}\text { Very low functioning capacity } \\
\text { Needs nursing }\end{array}$ & $\begin{array}{l}\text { Mild motor development } \\
\text { Unable to acquire personal autonomy } \\
\text { Needs permanent care }\end{array}$ & $\begin{array}{l}\text { Some motor development is observed } \\
\text { No development of language } \\
\text { Needs permanent care }\end{array}$ \\
\hline
\end{tabular}




\begin{tabular}{|c|c|c|c|c|c|c|c|c|c|c|c|c|c|c|c|c|c|}
\hline Family & No & Initials & Sex & $\begin{array}{l}\text { Year of } \\
\text { birth }\end{array}$ & $\begin{array}{l}\text { Weight at } \\
\text { birth (g) }\end{array}$ & $\begin{array}{l}\text { Age at } \\
\text { referral }\end{array}$ & Reason fo & $r$ referral & $\begin{array}{l}\text { Age at onset } \\
\text { of lipo }\end{array}$ & $\begin{array}{l}\text { Age at } \\
\text { onset of } \\
\text { diabetes } \\
\text { mellitus }\end{array}$ & $\begin{array}{l}\text { Intellectual } \\
\text { impairment }\end{array}$ & it Other clinical & features & $\begin{array}{l}\text { Age at } \\
\text { death }\end{array}$ & $\begin{array}{l}\text { Cause of } \\
\text { death }\end{array}$ & Ethnic background & $\begin{array}{l}\text { Parental } \\
\text { consang }\end{array}$ \\
\hline \multicolumn{18}{|l|}{ BSCL1 } \\
\hline $1^{*}$ & 1 & FV & $\mathrm{F}$ & 1974 & 3100 & $6 \mathrm{mth}$ & \multicolumn{2}{|c|}{ Failure to thrive } & $3 \mathrm{mth}$ & $26 y$ & Moderate & & - & - & Belgian & Y \\
\hline $2^{*}$ & 2 & $w x$ & M & 1977 & 2760 & $5 \mathrm{mth}$ & \multirow{2}{*}{\multicolumn{2}{|c|}{$\begin{array}{l}\text { Lipoatrophy } \\
\text { Diabetes }\end{array}$}} & Birth & & - & & & - & - & African - Caribbean & $\mathrm{N}$ \\
\hline $3^{*}$ & 3 & ZC & $\mathrm{F}$ & 1987 & - & $7 y$ & & & - & $7 y$ & - & \multicolumn{2}{|c|}{ Hypertrophic cardiomyopathy } & - & - & Algerian & $\mathrm{N}$ \\
\hline $4^{*}$ & 4 & DC & $\mathrm{F}$ & 1968 & - & $5 y$ & \multicolumn{2}{|c|}{ Weight loss } & $5 y$ & $13 y$ & - & \multirow{2}{*}{\multicolumn{2}{|c|}{$\begin{array}{l}\text { Pancreatitis (at } 7 \mathrm{y} \text { ) } \\
\text { Bone cysts }\end{array}$}} & - & - & African - mixed & $\mathrm{N}$ \\
\hline \multirow[t]{3}{*}{$5^{*}$} & 5 & $\mathrm{DiH}$ & $\mathrm{F}$ & 1972 & - & $11 \mathrm{y}$ & \multirow{2}{*}{\multicolumn{2}{|c|}{$\begin{array}{l}\text { Diabetes mellitus } \\
\text { Lipoatrophy, family } \\
\text { history }\end{array}$}} & $2 \mathrm{mth}$ & $7 y^{\prime}$ & Mild & \multirow{2}{*}{\multicolumn{2}{|c|}{$\begin{array}{l}\text { Bone cysts } \\
-\end{array}$}} & - & - & African - Senegal & Y \\
\hline & 6 & Dil & M & 1984 & 2570 & 6 wk & & & Birth & $\begin{array}{l}\text { Transient } \\
\text { hypergly- } \\
\text { caemia at } \\
\text { birth }\end{array}$ & - & & & - & - & African - Senegal & Y \\
\hline & 7 & $\mathrm{DiN}$ & $\mathrm{F}$ & 1987 & - & $9 \mathrm{mth}$ & \multicolumn{2}{|c|}{$\begin{array}{l}\text { Lipoatrophy, family } \\
\text { history }\end{array}$} & Birth & - & - & \multicolumn{2}{|l|}{-} & - & - & African - Senegal & Y \\
\hline $6^{*}$ & 8 & AL & $\mathrm{F}$ & 1983 & 2550 & 2 wk & \multicolumn{2}{|c|}{ Lipoatrophy } & Birth & - & - & \multicolumn{2}{|c|}{$\begin{array}{l}\text { Normal cardiac ultrasound, } \\
\text { clitoromegaly }\end{array}$} & - & - & African - Ghana & $\mathrm{N}$ \\
\hline $7^{*}$ & 9 & J & $\mathrm{F}$ & 1990 & - & - & \multicolumn{2}{|l|}{ - } & Birth & - & - & \multicolumn{2}{|c|}{-} & - & - & Moroccan & Y \\
\hline $8^{*}$ & 10 & $\mathrm{Rd}$ & M & 1991 & - & - & \multicolumn{2}{|c|}{-} & Birth & - & - & \multicolumn{2}{|l|}{-} & - & - & Turkish & Y \\
\hline \multirow[t]{3}{*}{$9^{*}$} & 11 & $\mathrm{HL}$ & $\mathrm{F}$ & 1962 & - & $3 y$ & \multirow{2}{*}{\multicolumn{2}{|c|}{$\begin{array}{l}\text { Lipoatrophy } \\
\text { Family history }\end{array}$}} & $3 \mathrm{wk}$ & - & - & \multirow{2}{*}{\multicolumn{2}{|c|}{ Bone cysts }} & - & - & African-American & $\mathrm{N}$ \\
\hline & 12 & HHD & $\mathrm{F}$ & 1965 & - & $9 \mathrm{mth}$ & & & Birth & - & - & & Bone cysts & - & - & African-American & $\mathrm{N}$ \\
\hline & 13 & HRD & M & 1969 & - & $6 y$ & \multicolumn{2}{|c|}{ Family history } & - & - & - & - & & - & - & African-American & $\mathrm{N}$ \\
\hline $10^{*}$ & 14 & $M$ & $\mathrm{~F}$ & 1990 & 3300 & $5 \mathrm{mth}$ & \multicolumn{2}{|c|}{ Lipoatrophy } & Birth & - & - & - & & - & - & Tunisian & Y \\
\hline $11^{*}$ & 15 & OU & $\mathrm{F}$ & 1964 & - & $23 y$ & Diabetes $n$ & ellitus & $23 y$ & $23 y$ & - & Hypertrophic & Eardiomyopathy & - & - & Algerian & Y \\
\hline $12^{*}$ & 16 & SMG & $\mathrm{F}$ & 1994 & - & $9 \mathrm{mth}$ & $\begin{array}{l}\text { Gigantism } \\
\text { lipoatroph }\end{array}$ & & Birth & - & - & Clitoromegaly & & - & - & German (Brazil) & Y \\
\hline $13^{*}$ & 17 & VV & $\mathrm{F}$ & 1975 & 3000 & $4 y$ & $\begin{array}{l}\text { Gigantism } \\
\text { precocious }\end{array}$ & puberty & Birth & - & - & Bone cysts, go & itre, macrocephaly & - & - & $\begin{array}{l}\text { African-Indian } \\
\text { (Caribbean) }\end{array}$ & N \\
\hline $14^{*}$ & 18 & BJ & M & 1993 & 2900 & $3 \mathrm{mth}$ & $\begin{array}{l}\text { Abdomina } \\
\text { hepatomes }\end{array}$ & $\begin{array}{l}\text { I pain, } \\
\text { yaly }\end{array}$ & Birth & - & - & Hypertrophic & ardiomyopathy & - & - & $\begin{array}{l}\text { African-Nigerian } \\
\text { (France) }\end{array}$ & $\mathrm{N}$ \\
\hline $15^{*}$ & 19 & EF & M & 1996 & 3440 & $3 \mathrm{mth}$ & $\begin{array}{l}\text { Facial dys } \\
\text { hepatomes }\end{array}$ & $\begin{array}{l}\text { morphism, } \\
\text { galy }\end{array}$ & $3 \mathrm{mth}$ & - & - & Hypertrophic & ardiomyopathy & - & - & Turkish & Y \\
\hline $16^{*}$ & 20 & $\mathrm{PH}$ & $\mathrm{F}$ & 1970 & - & $22 y$ & Diabetes & & $17 y$ & $22 y$ & - & - & & - & - & Dutch (South Africa) & $N$ \\
\hline $17^{*}$ & 21 & ZA & $\mathrm{F}$ & & - & $6 \mathrm{mth}$ & Lipoatroph & & Birth & - & - & - & & - & - & Moroccan (France) & Y \\
\hline Family & No & $\begin{array}{l}\text { Seipin amino } \\
\text { acid change }\end{array}$ & $\begin{array}{l}\text { Type of } \\
\text { seipin } \\
\text { mutation }\end{array}$ & Initials & Sex & $\begin{array}{l}\text { Year of } \\
\text { birth }\end{array}$ & $\begin{array}{l}\text { Weight at } \\
\text { birth }(g)\end{array}$ & $\begin{array}{l}\text { Age at } \\
\text { referral }\end{array}$ & $\begin{array}{l}\text { Reason for } \\
\text { referral }\end{array}$ & $\begin{array}{l}\text { Age at } \\
\text { onset of } \\
\text { lipo }\end{array}$ & $\begin{array}{l}\text { Age at } \\
\text { onset of } \\
\text { diabetes } \\
\text { mellitus }\end{array}$ & $\begin{array}{l}\text { Intellectual } \\
\text { impairment }\end{array}$ & $\begin{array}{l}\text { Other clinical } \\
\text { features }\end{array}$ & Age at death & Cause of death & Ethnic background & $\begin{array}{l}\text { Parental } \\
\text { consang }\end{array}$ \\
\hline BSCL2 & & & & & & & & & & & & & & & & & \\
\hline 1 & 1 & R138X/R138X & Non & MALF & $\mathrm{F}$ & 1965 & Normal & $24 y$ & $\begin{array}{l}\text { Diabetes, } \\
\text { acromegaloid } \\
\text { features }\end{array}$ & $6 \mathrm{mth}$ & 24 y /No & Mild & $\begin{array}{l}\text { Hypertrophic } \\
\text { cardiomyopathy }\end{array}$ & - & - & Portuguese & Y \\
\hline & 2 & R138X/R138X & Non & ML & $\mathrm{F}$ & 1967 & Normal & $20 y$ & Diabetes & Infancy & $15 y$ & Mild & Multinodular goitre & - & - & Portuguese & Y \\
\hline 2 & 3 & R138X/R138X & Non & HSDM & $\mathrm{F}$ & 1980 & - & $15 y$ & Diabetes & Infancy & $15 \mathrm{y}$ & Mild & - & - & - & Portuguese & Y \\
\hline 3 & 4 & $\begin{array}{l}\text { F63fss X75/ } \\
\text { F63fsX75 }\end{array}$ & Ins-del & DD & M & 1982 & 2900 & Birth & Lipoatrophy & Birth & - & Moderate & $\begin{array}{l}\text { Hypertrophic } \\
\text { cardiomyopathy }\end{array}$ & - & - & Italian (Sicily) & Y \\
\hline 4 & 5 & $\begin{array}{l}\text { DV99-S146/ } \\
\text { DV99-S146 }\end{array}$ & Splice site & AS & M & 1981 & 3120 & $3 \mathrm{mth}$ & Rickets & Birth & - & Moderate & $\begin{array}{l}\text { Persistent mullerian } \\
\text { ducts, vitamin D } \\
\text { resistant rickets }\end{array}$ & $14 y$ & Heart failure & Turkish & Y \\
\hline 5 & 6 & R138X/R138X & Non & FJ & M & 1992 & 3040 & $6 \mathrm{mth}$ & Dysmorphism & First year & - & No (IQ 101) & $\begin{array}{l}\text { Waddling gait, } \\
\text { prognathism, } \\
\text { hypertrophic } \\
\text { cardiomyopathy }\end{array}$ & - & - & Portuguese (France) & Y \\
\hline & 7 & R138X/R138X & Non & FS & M & 1996 & 3490 & $2 \mathrm{mth}$ & Family history & - & - & No (IQ 101) & $\begin{array}{l}\text { Waddling gait, } \\
\text { surgical cure of } \\
\text { macroglossia, } \\
\text { hypertrophic } \\
\text { cardiomyopathy }\end{array}$ & - & - & Portuguese (France) & Y \\
\hline
\end{tabular}




\begin{tabular}{|c|c|c|c|c|c|c|c|c|c|c|c|c|c|c|c|c|c|}
\hline Appen & dix 2 & continued & & & & & & & & & & & & & & & \\
\hline Family & No & $\begin{array}{l}\text { Seipin amino } \\
\text { acid change }\end{array}$ & $\begin{array}{l}\text { Type of } \\
\text { seipin } \\
\text { mutation }\end{array}$ & Initials & Sex & $\begin{array}{l}\text { Year of } \\
\text { birth }\end{array}$ & $\begin{array}{l}\text { Weight at } \\
\text { birth }\end{array}$ & $\begin{array}{l}\text { Age at } \\
\text { referral }\end{array}$ & $\begin{array}{l}\text { Reason for } \\
\text { referral }\end{array}$ & $\begin{array}{l}\text { Age at } \\
\text { onset of } \\
\text { lipo }\end{array}$ & $\begin{array}{l}\text { Age at } \\
\text { onset of } \\
\text { diabetes } \\
\text { mellitus }\end{array}$ & $\begin{array}{l}\text { Intellectual } \\
\text { impairment }\end{array}$ & $\begin{array}{l}\text { Other clinical } \\
\text { features }\end{array}$ & $\begin{array}{l}\text { Age at } \\
\text { death }\end{array}$ & $\begin{array}{l}\text { Cause of } \\
\text { death }\end{array}$ & Ethnic background & $\begin{array}{l}\text { Parental } \\
\text { consang }\end{array}$ \\
\hline \multirow[t]{2}{*}{6} & 8 & $\begin{array}{l}\text { Ala212Pro/ } \\
\text { Ala212Pro }\end{array}$ & Miss & $\mathrm{AE}$ & $\mathrm{F}$ & 1952 & $\begin{array}{l}2000 \text { at } \\
33 w\end{array}$ & Birth & Lipoatrophy & Birth & $12 y$ & Mild & $\begin{array}{l}\text { Hypertrophic } \\
\text { cardiomyopathy }\end{array}$ & $32 y$ & \multicolumn{2}{|c|}{$\begin{array}{l}\text { Post-intoxication Norwegian } \\
\text { renal failure, } \\
\text { pneumonia }\end{array}$} & $\mathrm{N}$ \\
\hline & 9 & $\begin{array}{l}\text { Ala212Pro/ } \\
\text { Ala212Pro }\end{array}$ & Miss & ME & M & 1957 & 4000 & $1 y$ & $\begin{array}{l}\text { Develop- } \\
\text { mental delay }\end{array}$ & Birth & - & - & $\begin{array}{l}\text { Angina pectoris, } \\
\text { bone cysts }\end{array}$ & - & - & Norwegian & $\mathrm{N}$ \\
\hline 7 & 10 & $\begin{array}{l}F 63 f s x 75 / \\
\text { F63fsX75 }\end{array}$ & Ins-del & KS & M & 1957 & 2500 & - & Lipoatrophy & Birth & $14 y$ & Moderate & $\begin{array}{l}\text { Hypertrophic } \\
\text { cardiomyopathy, } \\
\text { bone cysts }\end{array}$ & $35 \mathrm{y}$ & Renal failure & Norwegian & $\mathrm{N}$ \\
\hline 8 & 11 & $\begin{array}{l}\text { Ala212Pro/ } \\
\text { Ala21 } 12 \text { Pro }\end{array}$ & Miss & LSN & M & 1959 & 4100 & - & - & Birth & - & Moderate & $\begin{array}{l}\text { Hypertrophic } \\
\text { cardiomyopathy }\end{array}$ & - & - & Norwegian & N \\
\hline \multirow[t]{2}{*}{9} & 12 & $\begin{array}{l}\text { Ala212Pro/ } \\
\text { Ala212Pro }\end{array}$ & Miss & IT & $\mathrm{F}$ & 1961 & 3000 & $5 \mathrm{mth}$ & $\begin{array}{l}\text { Enlarged } \\
\text { tonsils }\end{array}$ & Birth & - & - & $\begin{array}{l}\text { Hypertrophic } \\
\text { cardiomyopathy }\end{array}$ & $24 y$ & $\begin{array}{l}\text { Heart failure } \\
\text { during } \\
\text { pregnancy }\end{array}$ & Norwegian & N \\
\hline & 13 & $\begin{array}{l}\text { Ala2 } 12 \text { Pro/ } \\
\text { Ala2 } 12 \text { Pro }\end{array}$ & Miss & TH & M & 1966 & 4030 & $2.5 \mathrm{mth}$ & Lipoatrophy & Birth & - & Moderate & $\begin{array}{l}\text { Hypertrophic } \\
\text { cardiomyopathy }\end{array}$ & - & - & Norwegian & $\mathrm{N}$ \\
\hline 10 & 14 & $\begin{array}{l}\text { Ala2 12Pro/ } \\
\text { F63fsX75 }\end{array}$ & $\begin{array}{l}\text { Miss/ } \\
\text { ins-del }\end{array}$ & OE & $\mathrm{F}$ & 1973 & 3550 & $2 \mathrm{mth}$ & Lipoatrophy & Birth & - & Mild & Bone cysts & - & - & Norwegian & Y \\
\hline \multirow[t]{3}{*}{11} & 15 & $\begin{array}{l}\text { F105fsX111/ } \\
\text { F105fsX111 }\end{array}$ & Del & Tba & M & 1991 & 3000 & $3 y$ & Lipoatrophy & Birth & - & $\begin{array}{l}\text { Moderate (IQ } \\
40)\end{array}$ & - & - & - & Lebanese & Y \\
\hline & 16 & $\begin{array}{l}\text { F105fsX111/ } \\
\text { F105fsX111 }\end{array}$ & Del & TCh & M & 1994 & 3000 & $9 \mathrm{mth}$ & Lipoatrophy & Birth & - & Mild & - & - & - & Lebanese & Y \\
\hline & 17 & $\begin{array}{l}\text { F105fsX111/ } \\
\text { F105fsX111 }\end{array}$ & Del & Tfa & M & 1968 & 2800 & 31 y & $\begin{array}{l}\text { Family } \\
\text { history }\end{array}$ & Birth & 31 y & Mild & - & - & - & Lebanese & Y \\
\hline \multirow[t]{2}{*}{12} & 18 & $\begin{array}{l}\text { F105fsX111/ } \\
\text { F105fsX111 }\end{array}$ & Del & EIA & M & 1989 & 2200 & $7 \mathrm{mth}$ & Lipoatrophy & Birth & - & Mild & - & - & - & Lebanese & Y \\
\hline & 19 & $\begin{array}{l}\text { F105fsX111/ } \\
\text { F105fsX111 }\end{array}$ & Del & EIAN & M & 1995 & - & $6 \mathrm{mth}$ & Lipoatrophy & Birth & - & Mild & - & - & - & Lebanese & Y \\
\hline \multirow[t]{2}{*}{13} & 20 & $\begin{array}{l}\text { F105s } x 111 / \\
\text { F105s } 1111\end{array}$ & Del & SJ & $\mathrm{F}$ & 1993 & 2250 & $3 \mathrm{mth}$ & $\begin{array}{l}\text { Lipoatrophy } \\
\text { hepato-megaly }\end{array}$ & $\begin{array}{l}\text { Birth } \\
y^{2}\end{array}$ & - & Moderate & - & - & - & Lebanese & Y \\
\hline & 21 & $\begin{array}{l}\text { F105fsX111/ } \\
\text { F105fsX111 }\end{array}$ & Del & SR & $\mathrm{F}$ & 1999 & 2400 & $2 \mathrm{mth}$ & $\begin{array}{l}\text { Lipoatrophy } \\
\text { hepato-megaly }\end{array}$ & $y^{\text {Birth }}$ & - & - & - & $4 \mathrm{mth}$ & Sepsis & Lebanese & Y \\
\hline 14 & 22 & $\begin{array}{l}\text { F105fsX111/ } \\
\text { F105fsX111 }\end{array}$ & Del & $\mathrm{Jfa}$ & $\mathrm{F}$ & 1987 & 3000 & $2 y$ & - & Birth & $8.5 \mathrm{y}$ & Mild & - & - & - & Lebanese & Y \\
\hline \multirow[t]{2}{*}{15} & 23 & $\begin{array}{l}\text { F105fsX111/ } \\
\text { F105fsX111 }\end{array}$ & Del & SSt & $\mathrm{F}$ & 1997 & 3120 & Birth & $\begin{array}{l}\text { Lipoatrophy } \\
\& \text { family } \\
\text { history }\end{array}$ & Birth & - & Moderate & $\begin{array}{l}\text { Precocious puberty } \\
\text { at } 4 \text { y, hirsutism, } \\
\text { liver cirrhosis, } \\
\text { hypertrophic } \\
\text { cardiomyopathy }\end{array}$ & - & - & Lebanese (USA) & Y \\
\hline & 24 & $\begin{array}{l}\text { F105fsX111/ } \\
\text { F105fsX111 }\end{array}$ & Del & SSe & M & 1996 & 3330 & $1 \mathrm{mth}$ & Lipoatrophy & Birth & - & Moderate & $\begin{array}{l}\text { Liver cirrhosis, } \\
\text { hypertrophic } \\
\text { cardiomyopathy }\end{array}$ & - & - & Lebanese (USA) & Y \\
\hline \multirow[t]{8}{*}{16} & 25 & $\begin{array}{l}\text { F105fsX111/ } \\
\text { F105fsX111 }\end{array}$ & Del & FE & M & 1987 & 3500 & $9 \mathrm{mth}$ & \multicolumn{2}{|c|}{$\begin{array}{l}\text { Hepato-megal Birth } \\
\text { acanthosis } \\
\text { nigricans }\end{array}$} & $12 y$ & Mild & - & - & - & Lebanese & Y \\
\hline & 26 & $\begin{array}{l}\text { F105fsX111/ } \\
\text { F105fsX1111 }\end{array}$ & Del & AS & $\mathrm{F}$ & 1969 & - & - & - & Birth & $24 y$ & Mild & - & 31 y & Liver cirrhosis & Lebanese & Y \\
\hline & 27 & $\begin{array}{l}\text { F105fsX111/ } \\
\text { F105s X111 }\end{array}$ & Del & $A G$ & $\mathrm{~F}$ & 1972 & - & - & - & Birth & $26 y$ & Mild & - & - & - & Lebanese & Y \\
\hline & 28 & $\begin{array}{l}\text { F105fsX111/ } \\
\text { F105fsX111 }\end{array}$ & Del & HS & M & 1989 & 2700 & $2 \mathrm{mth}$ & - & Birth & - & Mild & - & - & - & Lebanese & Y \\
\hline & 29 & $\begin{array}{l}\text { F105fsX111/ } \\
\text { F105fsX111 }\end{array}$ & Del & HP & M & 1992 & 3000 & $2 \mathrm{mth}$ & - & $1 \mathrm{mth}$ & - & Mild & - & - & - & Lebanese & Y \\
\hline & 30 & $\begin{array}{l}F 105 f_{s} \times 111 / \\
F 105 f_{s} \times 1111\end{array}$ & Del & GR & M & 2000 & 3200 & $1 \mathrm{mth}$ & - & & - & Mild & - & - & - & Lebanese & Y \\
\hline & 31 & $\begin{array}{l}\text { F105fsX111/ } \\
\text { F105fsX111 }\end{array}$ & Del & GG & M & 1966 & 3100 & $33 y$ & $\begin{array}{l}\text { Family } \\
\text { history }\end{array}$ & Birth & - & Mild & - & $31 \mathrm{y}$ & Heart failure & Lebanese & Y \\
\hline & 32 & $\begin{array}{l}\text { F105fsX111/ } \\
\text { F105fsX111 }\end{array}$ & Del & Gba & $\mathrm{F}$ & 1968 & 3000 & 31 y & $\begin{array}{l}\text { Family } \\
\text { history }\end{array}$ & Birth & $28 y$ & Mild & - & - & - & Lebanese & Y \\
\hline
\end{tabular}




\begin{tabular}{|c|c|c|c|c|c|c|c|c|c|c|c|c|c|c|c|c|c|}
\hline \multicolumn{18}{|c|}{ Appendix 2 continued } \\
\hline \multirow[t]{4}{*}{ Family } & No & $\begin{array}{l}\text { Seipin amino } \\
\text { acid change }\end{array}$ & $\begin{array}{l}\text { Type of } \\
\text { seipin } \\
\text { mutation }\end{array}$ & Initials & Sex & $\begin{array}{l}\text { Year of } \\
\text { birth }\end{array}$ & $\begin{array}{l}\text { Weight at } \\
\text { birth (g) }\end{array}$ & $\begin{array}{l}\text { Age at } \\
\text { referral }\end{array}$ & $\begin{array}{l}\text { Reason for } \\
\text { referral }\end{array}$ & $\begin{array}{l}\text { Age at } \\
\text { onset of } \\
\text { lipo }\end{array}$ & $\begin{array}{l}\text { Age at } \\
\text { onset of } \\
\text { diabetes } \\
\text { mellitus }\end{array}$ & $\begin{array}{l}\text { Intellectual } \\
\text { impairment }\end{array}$ & $\begin{array}{l}\text { Other clinical } \\
\text { features }\end{array}$ & $\begin{array}{l}\text { Age at } \\
\text { death }\end{array}$ & & & \\
\hline & 33 & \multirow{3}{*}{$\begin{array}{l}\text { F105fsX111/ } \\
\text { F105fsX111 } \\
\text { F105ffX111/ } \\
\text { F105fsX111 } \\
\text { F105fsX111/ } \\
\text { F105fsX111 }\end{array}$} & Del & Gbc & M & 1971 & 3200 & $28 y$ & \multirow{2}{*}{$\begin{array}{l}\text { Family } \\
\text { history } \\
\text { Lipoatrophy }\end{array}$} & Birth & \multirow[t]{2}{*}{ - } & Mild & $\begin{array}{l}\text { features } \\
-\end{array}$ & $\begin{array}{l}\text { death } \\
-\end{array}$ & death & $\begin{array}{l}\text { Ethnic background } \\
\text { Lebanese }\end{array}$ & $\begin{array}{l}\begin{array}{l}\text { Parental } \\
\text { consang }\end{array} \\
Y\end{array}$ \\
\hline & 34 & & Del & She & $\mathrm{F}$ & 1966 & 2500 & $9 \mathrm{mth}$ & & Birth & & Mild & - & - & - & Lebanese & $\mathrm{Y}$ \\
\hline & 35 & & Del & SEl & M & 1998 & 2500 & $1 \mathrm{mth}$ & $\begin{array}{l}\text { Lipoatrophy } \\
\& \text { family } \\
\text { history }\end{array}$ & $1 \mathrm{mth}$ & - & Mild & - & - & - & Lebanese & $\mathrm{Y}$ \\
\hline 17 & 36 & $\begin{array}{l}\mathrm{F} 213 \mathrm{fs} \times 231 / \\
\mathrm{F} 213 \mathrm{fs} \times 231\end{array}$ & Del & SN & M & 1985 & - & $4 \mathrm{mth}$ & $\begin{array}{l}\text { Organo- } \\
\text { megaly }\end{array}$ & Birth & $15 y$ & - & $\begin{array}{l}\text { Normal cardiac } \\
\text { ultrasound }\end{array}$ & - & - & Indian (UK) & Y \\
\hline 18 & 37 & $\begin{array}{l}\text { F101 fsX111/ } \\
\text { F101 fsX111 }\end{array}$ & Ins & MDSM & $\mathrm{F}$ & 1960 & Normal & $29 y$ & Diabetes & $3 \mathrm{mth}$ & $29 y$ & - & - & - & - & Portuguese (Brazil) & $\mathrm{Y}$ \\
\hline 19 & 38 & $\begin{array}{l}\text { F108fsX113/ } \\
\text { F108fsX113 }\end{array}$ & Ins & DSF & M & 1975 & 3320 & $6 y$ & Diabetes & ly & $6 y$ & Moderate & - & - & - & $\begin{array}{l}\text { Portuguese (South } \\
\text { Africa) }\end{array}$ & Y \\
\hline 20 & 39 & $\begin{array}{l}\text { F108fsX113/ } \\
\text { F108s X } 113\end{array}$ & Ins & GD & $\mathrm{F}$ & 1981 & - & $2 \mathrm{mth}$ & Lipoatrophy & Birth & $14 y$ & - & - & - & - & $\begin{array}{l}\text { Portuguese (South } \\
\text { Africa) }\end{array}$ & $\mathrm{N}$ \\
\hline \multirow[t]{2}{*}{21} & 40 & Del exons 4-6 & Del & $\underset{41}{\mathrm{HM} \text { twin }}$ & M & 1990 & $\begin{array}{l}2320 \text { at } \\
37 \mathrm{wk}\end{array}$ & $5 \mathrm{mth}$ & $\begin{array}{l}\text { Failure to } \\
\text { thrive }\end{array}$ & Birth & - & Mild & $\begin{array}{l}\text { IUGR, } \\
\text { polyhydramnios }\end{array}$ & - & - & Portuguese (France) & $\mathrm{Y}$ \\
\hline & 41 & Del exons 4-6 & Del & $\begin{array}{l}\text { HD twin } \\
40\end{array}$ & M & 1990 & 2050 at & $5 \mathrm{mth}$ & $\begin{array}{l}\text { Failure to } \\
\text { thrive }\end{array}$ & Birth & - & Mild & $\begin{array}{l}\text { IUGR, } \\
\text { polyhydramnios }\end{array}$ & - & - & Portuguese (France) & $\mathrm{Y}$ \\
\hline 22 & 42 & $\begin{array}{l}\mathrm{F} 105 \mathrm{fs} \times 112 / \\
\text { del } \mathrm{E} 5-6\end{array}$ & Del/del & RA & $\mathrm{F}$ & 1970 & - & Birth & Lipoatrophy & $3-6 \mathrm{mth}$ & $13 y$ & Moderate & - & - & - & Portuguese (France) & $\mathrm{N}$ \\
\hline 23 & 43 & $\begin{array}{l}\mathrm{F} 224 \Delta \mathrm{Y} 225- \\
\mathrm{Q} 271 \mathrm{fs} X 288\end{array}$ & Splice & $\mathrm{EL}$ & M & - & 2000 & Birth & Lipoatrophy & Birth & - & $\begin{array}{l}\text { Severe } \\
\text { psychomotor } \\
\text { delay, } \\
\text { pyramidal } \\
\text { signs }\end{array}$ & - & - & - & Turkish & Y \\
\hline \multirow[t]{2}{*}{24} & 44 & $\begin{array}{l}\text { Fo } 3 \mathrm{fs} \times 75 / \\
\mathrm{F} 224 \mathrm{~s} \times 225\end{array}$ & $\begin{array}{l}\text { Ins-del/ } \\
\text { splice }\end{array}$ & WM & M & 1985 & 4700 & $6 \mathrm{mth}$ & Lipoatrophy & Birth & - & - & - & - & - & British & $\mathrm{N}$ \\
\hline & 45 & $\begin{array}{l}\text { F63fsx75/ } \\
\text { F224fsX225 }\end{array}$ & $\begin{array}{l}\text { Ins-del/ } \\
\text { splice }\end{array}$ & WF & $\mathrm{F}$ & 1989 & 3800 & Birth & $\begin{array}{l}\text { Family } \\
\text { history }\end{array}$ & Birth & - & - & - & - & - & British & $\mathrm{N}$ \\
\hline Family & No & Initials & Sex & $\begin{array}{l}\text { Year of } \\
\text { birth }\end{array}$ & $\begin{array}{l}\text { Weight at } \\
\text { birth (g) }\end{array}$ & $\begin{array}{l}\text { Age at } \\
\text { referral }\end{array}$ & \multicolumn{2}{|c|}{ Reason for referral } & $\begin{array}{l}\text { Age at onset } \\
\text { of lipo }\end{array}$ & $\begin{array}{l}\text { Age at } \\
\text { onset of } \\
\text { diabetes } \\
\text { mellitus }\end{array}$ & $\begin{array}{l}\text { Intellectual } \\
\text { impairment }\end{array}$ & \multicolumn{2}{|c|}{ Other clinical features } & Age at death & Cause of death & Ethnic background & $\begin{array}{l}\text { Parental } \\
\text { consang }\end{array}$ \\
\hline \multicolumn{3}{|l|}{$B S C L X$} & & & & & & & & & & \multirow{3}{*}{\multicolumn{2}{|c|}{$\begin{array}{l}\text { Liver cirrhosis, thick, curly hair } \\
\text { Bone cysts }\end{array}$}} & & & & \\
\hline 1 & 1 & HP & $\mathrm{F}$ & 1980 & 2950 & $1 y$ & \multirow{2}{*}{\multicolumn{2}{|c|}{ Failure to thrive }} & $1 y$ & $2 y$ & - & & & $7.5 y$ & Liver failure & Czech Republic & $\mathrm{N}$ \\
\hline \multirow[t]{2}{*}{2} & 2 & RI & $\mathrm{F}$ & 1985 & 3250 & Birth & & & Birth & - & - & & & - & - & Belgian & $\mathrm{N}$ \\
\hline & 3 & RK & $\mathrm{F}$ & 1983 & 2350 & $13 \mathrm{mth}$ & \multirow{2}{*}{\multicolumn{2}{|c|}{$\begin{array}{l}\text { Failure to thrive } \\
\text { Reason for referral }\end{array}$}} & $5 \mathrm{wk}$ & - & - & \multicolumn{2}{|c|}{$\begin{array}{l}\text { Bone cysts } \\
\text { Bons }\end{array}$} & - & - & Belgian & $\mathrm{N}$ \\
\hline Family & No & Initials & Sex & $\begin{array}{l}\text { Year of } \\
\text { birth }\end{array}$ & $\begin{array}{l}\text { Weight at } \\
\text { birth (g) }\end{array}$ & $\begin{array}{l}\text { Age at } \\
\text { reterral }\end{array}$ & & & $\begin{array}{l}\text { Age at onset } \\
\text { of lipo }\end{array}$ & $\begin{array}{l}\text { Age at } \\
\text { onset of } \\
\text { diabetes } \\
\text { mellitus }\end{array}$ & $\begin{array}{l}\text { Intellectual } \\
\text { impairment }\end{array}$ & \multicolumn{2}{|c|}{ Other clinical features } & Age at death & Cause of death & Ethnic background & $\begin{array}{l}\text { Parent } \\
\text { consang }\end{array}$ \\
\hline \multicolumn{2}{|c|}{ Non-informative } & & & & & & & & & & & & & & & & \\
\hline 1 & 1 & sv & M & 1992 & $\begin{array}{l}2100 \text { at } 37 \\
w k\end{array}$ & Birth & $\begin{array}{l}\text { IUGR, } \\
\text { hepatosple }\end{array}$ & enomegaly & Birth & - & Moderate & \multicolumn{2}{|c|}{$\begin{array}{l}\text { Liver steatosis, hypertrophic } \\
\text { cardiomyopathy }\end{array}$} & $19 \mathrm{mth}$ & Cardiac failure & Czech Republic & \\
\hline
\end{tabular}


subjects were reported as having some degree of intellectual impairment, this was true of only $10 \%$ of the BSCLl subjects. Although this difference might be explained by the expression of seipin in the brain, such a tissue specific expression may also be independent from any type of mental retardation (Wolfram syndrome, Duchenne muscular dystrophy, merosin positive congenital muscular dystrophy) and does not therefore provide a definitive clue to its pathophysiology. The normal brain MRI reported in mentally retarded BSCL2 patients is also remarkable.

No clear correlation was apparent between the site and type of seipin mutation and intellectual impairment. Furthermore, affected subjects from different families, but harbouring the same mutation, were found to be discordant in terms of mental impairment in some instances. Clearly, given the complex and qualitative nature of cognitive functions, it is not surprising that its expression may be subject to multiple genetic and environmental modifiers.

In summary, BSCLl is a form of congenital lipodystrophy, most prevalent among subjects of African origin, which appears to be a milder disease than BSCL2. This is manifested by its more frequent presentation as a delayed or partial lipodystrophy, a lower occurrence of premature death, and a markedly lower incidence of intellectual impairment. These observations suggest that the causative gene in BSCLl, yet to be described, may turn out to have more restricted functions and/or a more limited expression pattern than seipin. Our findings emphasis the importance of attempting to make a molecular diagnosis of the syndromes of congenital lipodystrophy as this may aid both prognostication and genetic counselling.

\section{ACKNOWLEDGEMENTS}

We thank the patients, their families, and the referring physicians for their participation; A Lemainque, P Hilbert, L Bodson, F Cavallin, A Fauré, V La Villa, and S Pavek for genotyping; and D Recan and her colleagues for immortalising the lymphoblasts. We thank the rare diseases programme of the European Commission (Directorate-General XII) for its support and L'Aide aux Jeunes diabétiques, l'Association Française contre les Myopathies (AFM), the Anders Jahres Fund, Assistance Publique-Hôpitaux de Paris, INSERM, Medinnova, and Ministère de la Recherche for their constant encouragement and financial support. We also want to thank Christian Melot and Maurice Jottrand for their help in statistical analysis of the data.

\section{NOTE ADDED IN PROOF}

After submission of this paper, identification of the BSCLI gene was published by Agarwal A, et al (Nat Genet 2002;31:21-3). The AGPAT2 gene encodes a key enzyme in the biosynthesis of triacylglycerol. This is consistent wth the limited expression pattern hypothesised in our conclusion.

\section{Authors' affiliations}

L Van Maldergem, C S Albott, Centre de Génétique Humaine, Institut de Pathologie et de Génétique, Loverval, Belgium

J Magré, J Capeau, INSERM U 402, Faculté de Médecine Saint Antoine, Paris, France

T E Khallouf, Service de Pédiatrie, Hotel-Dieu de France, Beirut, Lebanon T Gedde-Dahl Jr, Department of Dermatology and Institute of Forensic Medicine, Rikshospitalet, Oslo, Norway

M Delépine, M Lathrop, Centre National de Génotypage, Evry, France O Trygstad, Department of Paediatrics, Rikshospitalet, Oslo, Norway E Seemanova, Department of Clinical Genetics, Charles University, Prague, Czech Republic

T Stephenson, Department of Child Health, University Hospital, Nottingham, UK

F Bonnici, Paediatric Endocrine Services, University of Cape Town, Cape, South Africa

V R Panz, Department of Medicine, University of the Witwatersrand Johannesburg, South Africa

J-L Medina, Department of Endocrinology, Hospital S Joäo, Porto, Portugal
P Bogalho, Unidade de Endocrinologia, Hospital Curry Cabral, Lisbon, Portugal

F Huet, Service de Pédiatrie, Hôpital d'Enfants du Bocage, Dijon, France S Savasta, Clinica Pediatrica, Policlinico S Matteo, Università di Pavia, Pavia, Italy

A Verloes, Centre de Génétique Humaine, CHU Sart-Tilman, Liège,

Belgium

J-J Robert, Service de Diabétologie Infantile, Hôpital Necker, Paris, France

H Loret (deceased), Service de Pédiatrie, CHU, Fort-de-France,

Guadeloupe

M de Kerdanet, Unité d'Endocrinologie Pédiatrique, CHU Rennes,

France

V R Panz, Department of Medicine, University of the Witwatersrand, Johannesburg, South Africa

J-L Medina, Department of Endocrinology, Hospital S Joäo, Porto, Portugal

P Bogalho, Unidade de Endocrinologia, Hospital Curry Cabral, Lisbon,

Portugal

F Huet, Service de Pédiatrie, Hôpital d'Enfants du Bocage, Dijon, France

S Savasta, Clinica Pediatrica, Policlinico S Matteo, Università di Pavia,

Pavia, Italy

A Verloes, Centre de Génétique Humaine, CHU Sart-Tilman, Liège,

Belgium

J-J Robert, Service de Diabétologie Infantile, Hôpital Necker, Paris,

France

H Loret (deceased), Service de Pédiatrie, CHU, Fort-de-France,

Guadeloupe

M de Kerdanet, Unité d'Endocrinologie Pédiatrique, CHU Rennes, France

\section{REFERENCES}

1 Berardinelli W. An undiagnosed endocrinometabolic syndrome: report of two cases. J Clin Endocrinol Metab 1954;14:193-204.

2 Seip M. Lipoatrophy and gigantism with associated endocrine manifestations: a new diencephalic syndrome? Acta Paediatr Scand 1959:48:555-74

3 Seip $M$, Trygstad O. Generalised lipodystrophy, congenital and acquired (lipoatrophy). Acta Paediatr Suppl 1996;413:2-28.

4 Moller DE, O'Rahilly S. Syndromes of severe insulin resistance: clinical and pathophysiological features. In: Moller DE, ed. Insulin resistance. New York: Wiley and Sons, 1993:49-81.

5 Taylor SI, Arioglu E. Genetically defined forms of diabetes in children. J Clin Endocrinol Metab 1999;84:4390-6.

6 Garg A. Lipodystrophies. Am J Med 2000;108: 143-52.

7 Reitman ML, Arioglu E, Gavrilova O, Taylor SI. Lipoatrophy revisited. Trends Endocrinol Metab 2000;11:410-16.

8 Gedde-Dahl T Jr, Trygstad O, Van Maldergem L, Magré J, van der Hagen C B, Olaisen B, Stenersen M, Mevag B. Genetics of the Berardinelli-Seip syndrome (congenital generalised lipodystrophy) in Norway: epidemiology and gene mapping. Berardinelli-Seip Study Group. Acta Paediatr Suppl 1996:413:52-8.

9 Magré J, Hilbert $P$, Desbois-Mouton C, Vigouroux C, Fauré S, Weissenbach J, Capeau J, Bonnicci A, Nivelon-Chevalier A, Gedde-Dah T, O'Rahilly S, D'Abronzo FH, Bachy A, Van Maldergem L and the Beradinelli-Seip study group. Search for the gene(s) responsible for Lipoatrophic diabetes. Eur J Hum Genet 1996:4:165A.

10 Garg A, Wilson R, Barnes R, Arioglu E, Zaidi Z, Gurakan F, Kocak N O'Rahilly S, Taylor SI, Patel SB, Bowcock AM. A gene for congenital lipodystrophy maps to human chromosome 9q34. J Clin Endocrinol Metab 1999:84:3390-4

11 Magré J, Delepine M, Khallouf E, Gedde-Dahl T Jr, Van Maldergem L, Sobel E, Papp J, Meier M, Megarbane A, Bachy A, Verloes A, D'Abronzo FH, Seemanova E, Assan R, Baudic N, Bourut C, Ćzernichow P, Huet F, Grigorescu F, de Kerdanet M, Lacombe D, Labrune P, Lanza M, Loret H, Matsuda F, Navarro J, Nivelon-Chevalier A, Polak M, Robert IJ, Tric P, Tubiana-Rufi N, Vigouroux C, Weissenbach J, Savasta S, Maassen JA, Trygstad O, Bogalho P, Freitas P, Medina HL, Bonnicci F, Joffe BI, Loyson G, Panz VR, Raal FJ, O'Rahilly S, Stephenson T, Kahn CR, Lathrop M, Capeau J, BSCL Working Group. Identification of the gene altered in Berardinelli-Seip congenital lipodystrophy on chromosome 1 lq13. Nat Genet 2001;28:365-70.

12 Heathcote K, Rajab A, Magré J, Syrris P, Besti M, Patton M, Delepine M, Lathrop M, Capeau J, Jeffery S. Molecular analysis of Berardinelli-Seip congenital lipodystrophy in Oman; evidence for multiple loci. Diabetes 2002;51:1291-3.

13 Van Maldergem L, Da Silva H, Freitas P, D'Abronzo FH. Berardinelli-Seip syndrome: a new Portuguese disease? Eur J Hum Genet 1998;6:74A.

14 Lawrence RD. Lipodystrophy and hepatomegaly with diabetes, lipemia, and other metabolic disturbances: a case throwing new light on the action of insulin. Lancet 1946;i:724-31, 773-5.

15 Mounkes LC, Burke B, Stewart CL. The a-type lamins. Nuclear structural proteins as a focus for muscular dystrophy and cardiovascular diseases. Trends Cardiovasc Med 2001;11:280-5.

16 Cao H, Hegele RA. Nuclear lamin A/C R482Q mutation in Canadian kindreds with Dunnigan-type familial partial lipodystrophy. Hum Mol Genet 2000;9:109-12. 
17 Shackleton S, Lloyd DJ, Jackson SN, Evans R, Niermeiier MF, Singh BM Schmidt H, Brabant G, Kumar S, Durrington PN, Gregory S, O'Rahilly S, Trembath RC. LMNA, encoding lamin $A / C$, is mutated in partial lipodystrophy. Nat Genet 2000;24:153-6.

18 Speckman RA, Garg A, Du F, Bennett L, Veile R, Arioglu E, Taylor SI, Lovett $M$, Bowcock AM. Mutational and haplotype analyses of families with familial partial lipodystrophy (Dunnigan variety) reveal recurrent missense mutations in the globular C-terminal domain of lamin A/C. Am J Hum Genet 2000:66:1 192-8.
19 Vigouroux C, Magré J, Vantyghem MC, Bourut C, Lascols O Shackleton S, Lloyd DJ, Guerci B, Padova G, Valensi P, Grimaldi A, Piquemal R, Touraine P, Trembath RC, Capeau J. Lamin A/C gene: sex-determined expression of mutations in Dunnigan-type familial partial lipodystrophy and absence of coding mutations in congenital and acquired generalised lipoatrophy. Diabetes 2000;49: 1958-62.

20 Brunzell JD, Shankle SW, Bethune JE. Congenital generalized lipodystrophy accompanied by cystic angiomatosis. Ann Intern Med 1968;69:501-16.

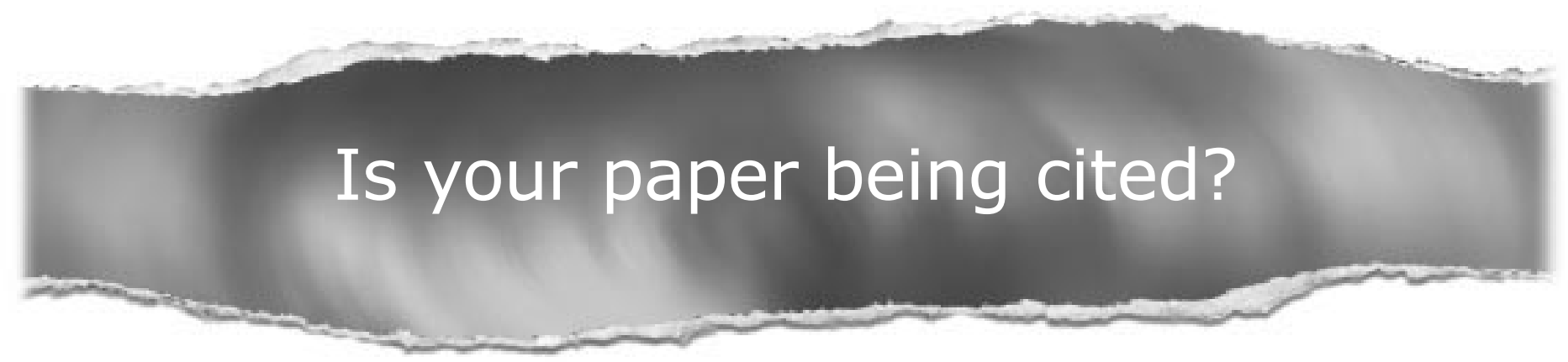

\section{CiteTrack service}

CiteTrack will alert you by email whenever new content in the Journal of Medical Genetics or a participating journal is published that matches criteria you want to track

Topics: Tell CiteTrack which words or subjects to watch for in new content Authors: Be alerted whenever key authors you are following publish a new paper Articles: Know whenever a paper of interest to you is referenced by another paper

www.jmedgenet.com 


\section{PostScript}

\section{BOOK REVIEW}

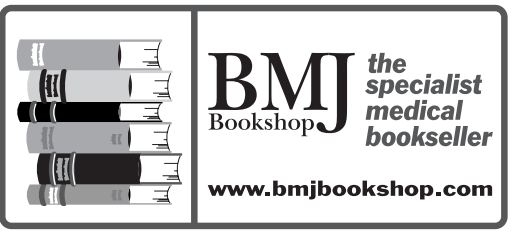

\section{Molecular Cytogenetics Protocols and Applications}

Methods in Molecular Biology Volume 204 Editor Yao-Shan Fan. (Pp 424; \$135.00. Totowa, NJ: Humana Press. 2002. ISBN 1-58829-006-9.

This book is a very up to date manual covering the background, methodologies, and applications of molecular cytogenetics techniques. The emphasis is on the diagnostic applications of FISH in the many areas of medicine on which it impinges, including paediatrics, fetal and reproductive medicine, pathology, haematology, oncology, and, of course, medical genetics. With 27 chapters and over 60 authors, all of whom are experts in their field this book clearly shows how far molecular cytogenetics techniques have developed over the last two decades.

The book is divided into three parts. Part 1 covers the basic concepts and techniques. The opening chapter by the editor Yao-Shan Fan provides a very helpful overview of the scope of the book and an extensive set of references for further reading. The following chapters cover probe labelling (DNA and RNA probes) and basic FISH techniques. The second part of the book is devoted to evolving techniques and applications and includes chapters on microdissection, PRINS, SKY FISH, M FISH, CGH, colour banding FISH, fibre FISH, multitelomere FISH, fluorescence genotyping for telomeric regions, and microarray CGH. Spe cial applications of molecular cytogenetic techniques in chromosomal disorders are cov ered in part 3 of the book. These includ chapters on the application of FISH to the delineation of marker chromosomes and the diagnosis of microdeletion syndromes. Other chapters cover FISH interphase nuclei screening for prenatal diagnosis including preimplantation diagnosis and fetal cells in the maternal circulation, in addition to the interphase FISH screening of routine amniotic fluid samples. This section concludes with a chapter on the application of FISH and CGH in reproductive pathology. The fourth and final section of the book covers the application of molecular cytogenetic techniques to cancer diagnosis. Chapters include the use of CGH in cancer investigations and the application of interphase FISH for the BCR/ABL rearrangements in CML and for HER2 amplification in breast cancer. Also included in this section are the interesting combined approaches, firstly of chromogenic in situ hybridisation with FISH in pathology and secondly simultaneous fluorescence immunophenotyping and FISH on tumour cells.

With any multiauthor book, there are bound to be differences in approach to the writing of individual contributions. This book has taken a surprisingly consistent approach, perhaps an illustration of good editorial control. All of the chapters have good introductory sections and are well referenced, as well as containing the authors' preferred methodologies. Each chapter also includes a comprehensive notes section (effectively tips and troubleshooting advice from the experts). However, a major problem with the book is the lack of comparison between different molecular techniques. In the preface, it is suggested that the book should help the technologist or cytogeneticist determine which procedure to perform for an informative result. I am not sure that the book provides this, as most if not all of the contributors are bound to select their own preferred methodology. For example, in the chapter on FISH screening for telomere abnormalities, an otherwise excellent chapter by Samantha Knight and Jonathan Flint, the practical application of only one of the two commercially available probe sets for this test is covered. More importantly, elsewhere in the book there is a first class chapter on interphase FISH for prenatal diagnosis of common aneuploidies by Baruch Feldman et al. This covers the topic extremely comprehensively and provides 89 literature citations. However, there is no mention, as far as I could see, throughout the book of the other alternative molecular approach of quantitative fluores cence PCR for prenatal aneuploidy detection. While it may be reasonable to excuse the editor by saying that the book is not designed to cover purely molecular genetic techniques, in the same section as the prenatal FISH, there is a chapter on the molecular detection of uniparental disomy. This chapter sits rather incongruously among the others, but is in itself a useful and important topic. Another chapter which seems to have lost its place describes the BAC resource for molecular cytogenetics. This is the final chapter in the book, which appears to have been added as an afterthought. Surely this should have been in evolving techniques and applications rather than "special applications in oncology". The oncology applications would also have benefited from more chapters, for example, haematological disorders other than CML, solid tumour FISH (other than HER2), and perhaps a chapter on the screening of urine samples for bladder cancer.

Perhaps these topics are covered in the companion volume (Methods in molecular biology, volume 220. Cancer cytogenetics: methods and protocols). Another criticism is that the provision of colour plates is very variable. Some chapters are well illustrated, others less so. For example, the chapter on SKY FISH relies on black and white illustrations, whereas the MFISH chapter has glorious full colour images. Furthermore, the overall size of the book is relatively small $(16 \mathrm{~cm}$ by $24 \mathrm{~cm}$ ) and the size of typesetting and tight layout does not make for easy reading when compared with, for example, Rooney's "Human cytogenetics: a practical approach".

On the plus side, there is an incredibly large amount of information packed into this volume, none of it superfluous. Although other textbooks that cover FISH techniques are available, this book provides a more comprehensive, up to date, and thorough coverage of diagnostic molecular cytogenetics than any of the other books currently available.

In summary, I would recommend it as a reference source for everyone working in and interested in the exciting field of diagnostic and research molecular cytogenetics.

Lionel Willatt 


\section{NOTICE}

\section{European Human Genetics \\ Conference 3 - 6 May 2003 ICC, Birmingham, England}

Plenary sessions

- Low Penetrance Genes and Cancer Susceptibility

- Public Issues - Population DNA Banks

- Recent Developments in Neurogenetics

\section{Symposia}

- Bioinformatics

- Stem cells

- Sensory genetics

- Alternative splicing

- Cancer genetics

- Alzheimer disease

- SNPs and haplotypes

- Chromosomes in genetic disease

- Genetics and endocrine problems

\section{Workshops}

- Syndrome identification

- Cytogenetics

- Problems in counselling/ethics

- Genotyping and mutation detection arrays - practical problems

- Quality control

- Prenatal cytogenetics

- Community genetics

\section{Abstract deadline}

Will be via world wide web. Closing date 13 January 2003.

Further information available from: The Vienna Medical Academy of Postgraduate Medical Education and Research, Alserstrasse 4, A-1090 Vienna, Austria. Tel +431 4051383 22 Email:eshg@medacad.org

\section{CORRECTIONS}

In the October 2002 issue of the journal, in the paper by Van Maldergem et al ( $\mathrm{J}$ Med Genet 2002;39:722-33), we regret that some of the authors' names and affiliations were inadvertently omitted. They were:

N Tubiana-Rufi

Service d'Endocrinologie Pédiatrique, Hôpital Robert-Debré, Paris, France

A Mégarbané

Unité de Génétique Médicale, Université Saint-Joseph, Beirut, Lebanon

J Maassen

Silvius Laboratory, University of Leiden Medical Centre, Leiden, The Netherlands

M Polak

INSERM U457, Université Paris VIII, Paris, France
D Lacombe

Service de Génétique Médicale, Hôpital Pellegrin-Enfants, Bordeaux, France

C R Kahn

Joslin Diabetes Center, Harvard University, Boston, USA

E L Silveira

Private Practice, Porto Alegre, Brazil

F H D'Abronzo

Department of Endocrinology, Faculdade de Medicina de Jundiaí, Brazil

F Grigorescu

Molecular Endocrinology, IURC, Montpellier, rance

S O'Rahilly

Department of Medicine and Clinical Biochemistry, Addenbrooke's Hospital, Cambridge, UK

In the July 2002 issue of the journal, in the Online mutation report by Olivieri et al (p e39), there was a missprint in table 2. For No 12 the mutation should have been $031 \mathrm{G}>\mathrm{T}$ instead of $1006 \mathrm{G}>\mathrm{T}$.

In the December 2002 issue of the journal, in the paper by Khoo et al (pp 906-912), all c.1732delTCinsAC mutations should read C.1732delTCinsA. This error occurs on page 906 (Abstract) and page 910 (Discussion). 